\title{
Metodika analýzy aktérů
}

\author{
Martin Zahradník, Jana Dlouhá
}

Envigogika 11 (1) - Metodiky/ Methodologies

Published/ Publikováno 6. 4. 2016

DOI: $10.14712 / 18023061.527$

\begin{abstract}
Abstrakt
Analýza aktérů mapuje určitý problém z pohledu zúčastněných aktérů, všímá si jejich zájmů, role, vzájemných vztahů, a vlivu na vývoj ve sledované oblasti. Jejím cílem je tak určit, v jakém sociálním prostředí se určitá aktivita odehrává nebo bude odehrávat, což v praxi může vést k posilování žádoucích vztahů a omezování potencionálních konfliktů. Cílem této metodiky je zpřístupnit metodu analýzy aktérů pro uplatnění v řešení konkrétních otázek rozhodování ve věcech veřejných. Poskytuje přehledný návod postupu analýzy krok za krokem, od vymezení problému a identifikace sociálních skupin (aktérů), přes jejich charakteristiku až po návrh konkrétních opatření. Metodika tak má sloužit k podpoře participativních postupů při hledání řešení v situacích, kde se střetávají zájmy různých sociálních aktérů; navíc může zprostředkovat zapojení odborné veřejnosti do zkoumání otázek spojených s participativním rozhodováním; Ize ji využít též v rámci výuky vedené v kontextu reálných situací. Představená metodika se opírá o zkušenosti autorů a uvádí př́iklady uplatnění z oblasti rozhodování v otázkách životního prostředí. Její působnost není limitována konkrétním oborem; své uplatnění má v rozhodování orientovaném na budoucí vývoj, při plánování a strategickém rozhodování v různorodém sociálním prostředí.
\end{abstract}




\section{Metodika \\ analýzy aktérů}

MARTIN ZAHRADNÍK, JANA DLOUHÁ

Návrh metodiky byl zpracován v rámci projektu TD020120 Studium a podpora procesů participativni tvorby regionálních strategií udržitelného rozvoje územís využitím metody analýzy aktérů, podpořeného Technologickou agenturou ČR v letech 2014-2015

Centrum pro otázky životního prostředí, Univerzita Karlova v Praze

Oponenti:

RNDr. Jan Plesník, CSc., Agentura ochrany prírody a krajiny ČR

PhDr. Ing. Pavel Mička, Agora Central Europe

Leden 2016 


\section{Obsah}

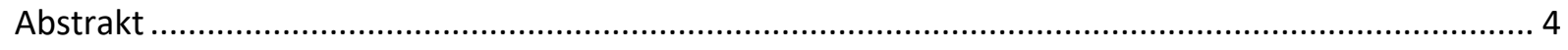

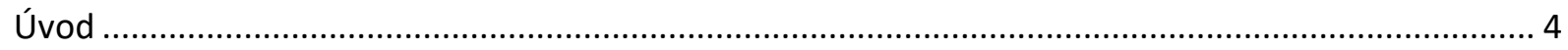

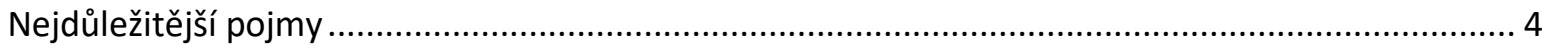

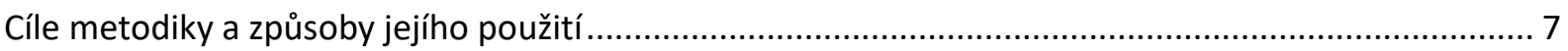

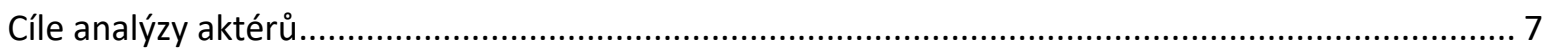

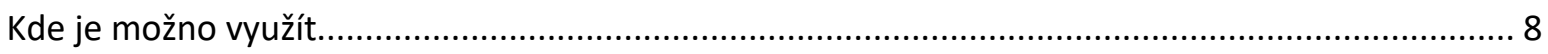

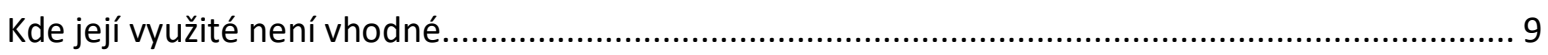

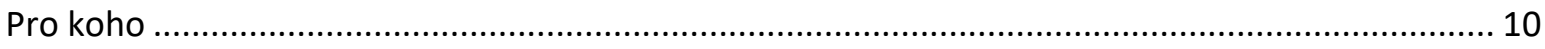

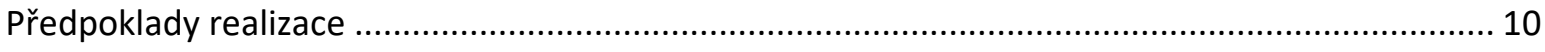

Ekonomické př́nosy a potřeby při analýze aktérů ........................................................ 12

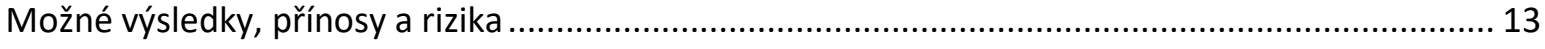

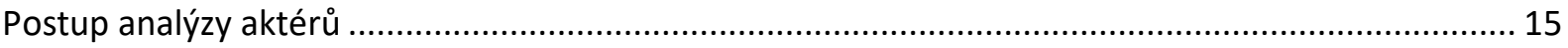

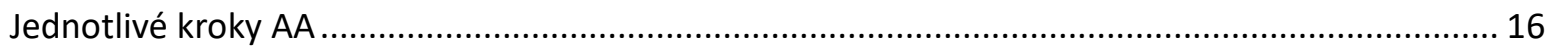

Definice problému/výzkumná otázka.................................................................... 16

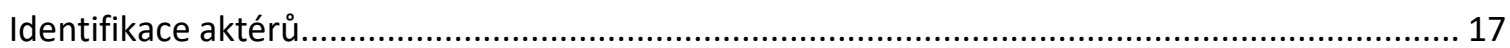

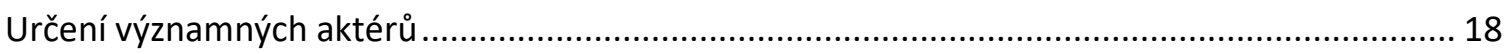

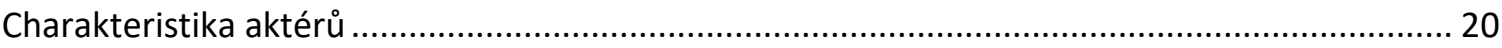

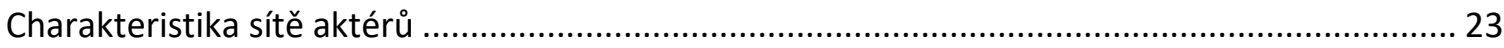

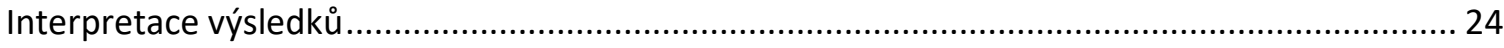

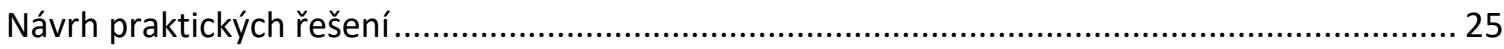

Další nástroje pro charakteristiku vztahů mezi aktéry .................................................... 27

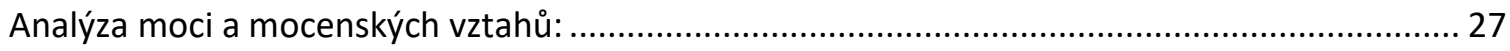

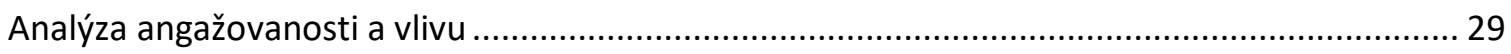

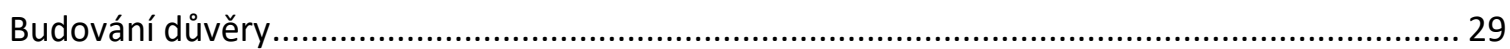

Vyloučení versus zvýšení vlivu ............................................................................... 30

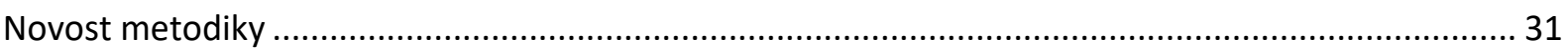

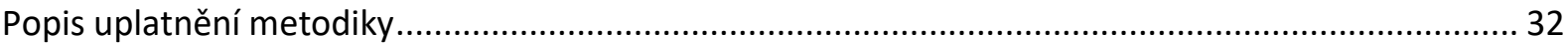

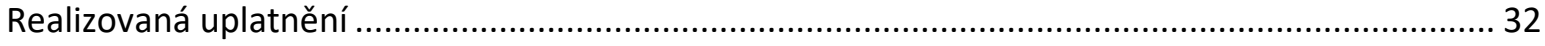

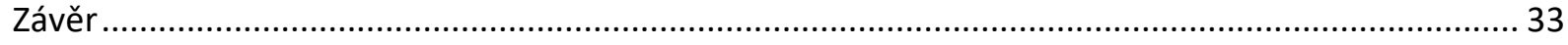

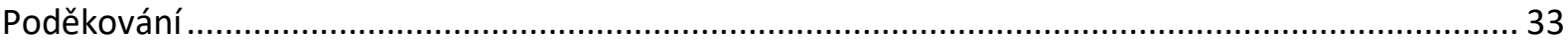

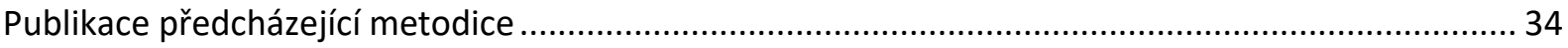

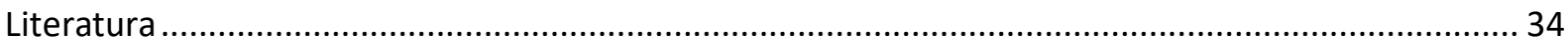




\section{Abstrakt}

Analýza aktérů mapuje určitý problém z pohledu zúčastněných aktérů, všímá si jejich zájmů, role, vzájemných vztahů, a vlivu na vývoj ve sledované oblasti. Jejím cílem je tak určit, v jakém sociálním prostředí se určitá aktivita odehrává nebo bude odehrávat, což v praxi může vést k posilování žádoucích vztahů a omezování potencionálních konfliktů. Cílem této metodiky je zpřístupnit metodu analýzy aktérů pro uplatnění v řešení konkrétních otázek rozhodování ve věcech veřejných. Poskytuje přehledný návod postupu analýzy krok za krokem, od vymezení problému a identifikace sociálních skupin (aktérů), přes jejich charakteristiku až po návrh konkrétních opatření. Metodika tak má sloužit k podpoře participativních postupů při hledání řešení v situacích, kde se střetávají zájmy různých sociálních aktérů; navíc může zprostředkovat zapojení odborné veřejnosti do zkoumání otázek spojených s participativním rozhodováním; Ize ji využít též v rámci výuky vedené v kontextu reálných situací. Představená metodika se opírá o zkušenosti autorů a uvádí př́iklady uplatnění z oblasti rozhodování v otázkách životního prostředí. Její působnost není limitována konkrétním oborem; své uplatnění má v rozhodování orientovaném na budoucí vývoj, při plánování a strategickém rozhodování v různorodém sociálním prostředí.

\section{Úvod}

Analýza aktérů (dále jen $\mathrm{AA}$ ) je metoda popisu sociálního prostředí z hlediska zúčastněných sociálních skupin (aktérů) - jejich zájmů, role, vzájemných vztahů, a vlivu na (udržitelný) rozvoj ve sledované oblasti. Předložená metodika pak přináší možnosti využití metody AA v praxi-především v rozhodovacích procesech, a to v kontextu České republiky. Ukazuje podmínky, ve kterých ji Ize využít, postup při této analýze, její možné výsledky a př́nosy, ale i omezení. Je praktickým návodem, který by měl pomoci při rozhodování na různých úrovních, kde je potřeba si uvědomit různé zájmy a názory týkající se problematiky, o které se právě jedná. Díky tomu lze rozhodovat demokraticky a současně předcházet případným střetům a konfliktům. Autoři metodiky se zabývají především životním prostředím a s ním souvisejícím uplatněním analýzy aktérů. Její působnost však není limitována konkrétním oborem. Tato metodika má široké uplatnění při př́pravě strategií - tedy vždy, když je třeba utvářet vize budoucího rozvoje, a hledat cesty $\mathrm{k}$ jejich naplnění v různorodém sociálním prostředí.

Představená metodika vznikla na základě poznatků odborných studií z českého prostředí i ze zahraničí; shrnuje vlastní zkušenosti týmu Centra pro otázky životního prostředí UK při její aplikaci v různých kontextech. Je návodem, jak postupovat při identifikaci a mapování sítě společenských aktérů s jejich zájmy a cíli, což umožňuje předcházet př́padným konfliktním situacím a otevírá prostor pro vzájemnou spolupráci. Její využití tak může být pokládáno za příspěvek k rozvoji dobrých vztahů v určitém (geograficky, tematicky atd.) vymezeném případu.

\section{Nejdůležitější pojmy}

Aktér je jednotlivec nebo skupina lidí, kteří jednají v určitém sociálním prostředí a mají zájem na jeho celkové podobě, dílčím tématu nebo konkrétním výsledku. Jejich jednání má vliv na systém či procesy $v$ dané situaci, a to protože jsou jimi ovlivněni nebo je mohou ovlivnit (mají určitou moc, legitimitu nebo znalosti). Místo pojmu aktér (actor) se ve stejném významu používá slovo „hráč" (stakeholder), což je termín odvozený z hráčského prostředí a v původním významu znamená ten, kdo má „něco 
v sázce“; v přeneseném smyslu označuje jedince či skupinu lidí, kteří mají k řešení daného případu nějaký vztah (mají zájem o určitý výsledek nebo na ně bude mít řešení nějaký dopad). V anglosaském prostředí se tento pojem používá spišse v souvislostech praxe, kdežto termín aktér je více vědecký, ale často se tyto významy zaměňují; v češtině, která nemá adekvátní překlad, pojmy splývají úplně.

Klíčový aktér je jednotlivec nebo organizace, která má kličcvý význam pro realizaci strategie či projektu, nebo mu zásadním způsobem brání.

Aktéři jsou definováni vždy ve vztahu k řešenému problému (podle okolností konkrétně nebo více obecně). Příkladem společenských aktérů, kteří byli definováni v rámci srovnávací analýzy př́padových studií z českého prostředí autory této metodiky, je následující jejich výčet: obec/město; NNO (i spolky a občanská sdružení); stát (ministerstva, vláda); státní podniky (např. Lesy ČR); velké komerční firmy (např. Czech Coal, developerské firmy); představitelé ochrany př́rody (CHKO, NP); místní podnikatelé a další komerční subjekty; školy; vědci; experti (komerční, z NNO); veřejnost (Ize specifikovat blíže: např. místní obyvatelé); zástupci kraje (a jeho úřadů); sportovní oddíly, zájmové kroužky, DDM a další výchovná zařizení (dětský domov, pedagogicko-psychologická poradna); a další.

Vymezení konkrétních skupin v tomto prípadě vycházelo z úvodního seznamu aktérů, který byl postupně rozšiřován nebo detailněji členěn podle jejich výskytu a role ve zkoumaných př́padech.

(Bližší informace k výčtu aktérů v kapitole Identifikace aktérů)

Analýza aktérů (AA, actor analysis, stakeholder analysis) je metoda popisu aktérů a jejich vztahů; používá se primárně v rámci rozhodování o budoucím rozvoji, změně, inovaci nebo intervenci v daném místě nebo případu. Lze ji aplikovat v situaci, kdy do hry vstupují různé pohledy, hodnoty a zájmy a kdy zmapování rolí sociálních aktérů může pomoci řešit konkrétní problém. Metoda AA je často využívána jako manažerský nástroj (také jako součást tvorby politik, výzkumu či výuky), a to v situacích, kdy je třeba popsat individuální a kolektivní aktéry, porozumět jejich vztahům a zmapovat interakce, které by mohly vyústit v e společensky významné aktivity. $\vee$ širším smyslu je analýzu aktérů možné uplatnit všude tam, kde dochází nebo kde lze očekávat střet zájmů různých sociálních skupin.

Metoda AA versus Metodika AA - metoda je ustálená cesta, způsob nebo postup, s jehož pomocí dosáhneme stanoveného výzkumného cíle. Lze ji proto použít pro výzkumné účely; $k$ tomu je třeba brát do úvahy její teoretická východiska, využít ověřené nástroje pro získání informací, a diskutovat omezení zvoleného postupu. Je však možné ji úspěšně využít pro praktické účely. Metodika slouží především praktickým cílům a jde tedy spíše o návod, manuál pro použití daných metod krok za krokem. Její modifikace pro různé situace je možná, avšak i zde je třeba dbát na nezávislost a spolehlivost postupu, např́klad pracovat s podloženými zdroji informací a všemožně omezovat riziko ovlivňování výstupů (viz kapitola Charakteristika aktérů).

Participace znamená podíl na rozhodování ve veřejných záležitostech a přináší určité nové rozložení moci či vlivu mezi občany (a dalšími aktéry) na jedné straně a veřejnými rozhodovateli na straně druhé (politickými a správními institucemi) - jde o nový způsob sdílení moci či vymezení podílu na ní (srovnej PAKT, 2015b: 6).

Participativní rozhodování je projevem politické kultury, v niž jsou občané aktivní součástí politického systému. Př́nosem je zlepšení vztahů a důvěry mezi občany a politiky, zejména na místní a regionální úrovni. Ve veřejné politice pak se participativní rozhodování projevuje v konceptu Governance, tedy decentralizovaného vládnutí a správy věcí veřejných (srovnej PAKT, 2015a: 5). 
Je možné určit různé stupně participace. $V$ praxi se proto používá tzv. participační žebřík. Příkladem může být pětistupňový participační žebřík, který připravil tým CESES FSV UK a v praxi jej používá iniciativa PAKT a. Tento žebřík obsahuje jednotlivé stupně participace (vzestupně): nejnižším stupněm je informování, dále pak připomínkování, konzultace, partnerství a nakonec nejvyšší stupeň, přenos rozhodování do rukou občanů (PAKT, 2015b: 7; CESES 2014).

Občanská participace je zapojení občanů do řešení věcí veřejných nezávisle na státu a ekonomické sféře. Může být součástí práce občanských sdružení /spolků a neziskových organizací, může ale být na jejich činnosti nezávislá. (Pergler, 2015). V této formě participace jsou zapojeni občané, což jsou ti, se kterými rozhodovatelé svou moc sdílejí, a to nejen formálně, ale též prakticky ve snaze přibližit jinak obtí̌ně dosažitelné a srozumitelné úřední a politické postupy veřejnosti (PAKT, 2015b: 6).

Podklady pro rozhodování zahrnují celou nebo částečnou vizi, analýzu situace, cíle, úkoly a dopady; a pokyny pro implementaci, realizaci, sledování, hodnocení a aktualizování. (Pergler, 2015)

Projekt je dočasné úsilí vynaložené na vytvoření unikátního produktu, služby, nebo určitého výsledku (dle definice A Guide to the Project Management Body of Knowledge, $4^{\text {th }}$ ed, PMI 2008). (Pergler, 2015)

Strategie je konkrétní střednědobý úmysl, jak ošetřit komplexní problém a navrhnout, jaké budou dopady řešení, jinými slovy "co dělat a kam to povede“. Strategie typicky popisuje ověřenou možnost realizace a uvádí obranu proti rizikům; její součástí bývá hodnocení procesu, kterým byla strategie připravena. (Pergler, 2015)

Vize je obecný souhrn dlouhodobých analýz, principů, cílů, zaměření a odhadovaných dopadů. Tyto prvky jsou vyžadovány zvláště při prípravě vize jako samostatného materiálu. Vize je však také součástí strategie. Podle definice, rozšířené v českém prostředí, je vizí popis žádoucího budoucího stavu, kterého chceme prostřednictvím realizace strategie dosáhnout. Vztahuje se tedy na strategii jako celek; podle ní se orientují strategické cíle. K naplnění vize by mělo dojít ve střednědobém či dlouhodobém horizontu (což nemusí být bezprostředně po ukončení realizace strategie). (dle Metodiky př́pravy veřejných strategii 2013).

Strategický rámec je vrcholný strategický dokument stanovující základní strategické cíle v dané oblasti/sektoru. Dle metodiky př́pravy veřejných strategií takový dokument nedefinuje vizi.

Veřejnost - pojem se užívá ve významu jednotlivých skupin obyvatel, které nemají povahu aktéra, protože $v$ dané situaci nemají vlastní výrazný zájem ( $v$ tomto smyslu používáme pojem $v$ této Metodice, viz kapitola Identifikace aktérů), nebo souhrnu těchto skupin či aktérů. V oficiálních dokumentech se rozlišuje např́klad „....veřejnost odborná a laická. Mezi odbornou veřejnost Ize začlenit profesní organizace, akademickou sféru, nestátní neziskové organizace, mezinárodní organizace a jednotlivce. Veřejnost lze také dělit na veřejnost ,organizovanou', kam patří odborné organizace, zájmové skupiny a podobně a veřejnost ,neorganizovanou'. Veřejností se rozumí také odborové organizace a organizace zaměstnavatelů. Zapojení těchto organizací sociálních partnerů se řídí zejména zákoníkem práce." (MV, 2010) I neorganizovanou veřejnost Ize však vymezit konkrétněji než pouze jako individuální občany, a to podle určitého znaku, zájmu či potencionálního dopadu řešení na ni (jako např. rodiny s dětmi, cyklisté, senioři, pejskaři, apod.) (viz PAKT 2015b: 31). 


\section{Cíle metodiky a způsoby jejího použití}

Metoda analýzy aktérů, stejně jako ostatní metody orientované na rozbor situace z pohledu zainteresovaných sociálních skupin a institucí, má především sloužit potřebám praxe, což je v souladu se společným původem těchto metod $v$ manažerské oblasti ( $v$ aplikované systémové analýze a operační analýze, viz (Hermans, Thissen, 2009)).

Jejím cílem je tak určit, v jakém sociálním prostředí se určitá aktivita odehrává nebo bude odehrávat, což v praxi může vést k posilování žádoucích vztahů a omezování potencionálních konfliktů. Otevírá dále prostor pro zapojení odborníků s vědeckými výzkumnými cíli do řešení konkrétní situace $v$ určitém místě či regionu a může se stát součástí kvalitativního výzkumu, např. v rámci př́padové studie nebo pro zobecnění více prípadových studií s cílem diskutovat teoretické předpoklady v oblasti participativního rozhodování (zde poskytuje strukturu pro zpětnou srovnávací analýzu případů). Možné je také kombinovat vědecký př́stup s praktickými cíli v podobě tzv. akčního výzkumu.

\section{Cíle analýzy aktérů}

Analýza aktérů se uplatňuje vždy ve vztahu ke konkrétnímu problému, jehož řešení závisí na dohodě mezi společenskými hráči na určité úrovni. Jejím cílem je odkrýt souvislost mezi sledovanými jevy či procesy, a společenskými vztahy, které je ovlivňují. Pokud se provádí pro řešení určitého problému, Ize s její pomocí identifikovat a charakterizovat všechny aktéry, kteří jsou tímto řešením nějakým způsobem dotčeni nebo kteří na něm mají vlastní zájem a usilují o vliv na výsledek rozhodovacích procesů. Analýza dále pracuje s motivacemi a s cíli těchto skupin, ukazuje prostředky, které používají k jejich dosahování (včetně způsobů komunikace), a shrnuje tyto charakteristiky, jež jsou pak využitelné např. v praktických otázkách rozvoje území. Základním cílem je postihnout povahu a roli každého z aktérů v konkrétním procesu změny, a popsat jejich vzájemné vazby, což přispívá k utváření transparentního prostředí pro vyjednávání.

Díky tomu pomáhá analýza aktérů zpřehlednit procesy rozhodování, nastavit vztahy důvěry mezi společenskými skupinami, posílit celkovou důvěryhodnost rozhodovacího procesu jako takového, což dále souvisí s ochotou občanů participovat na věcech veřejných. Záleží vždy na konkrétní situaci, v kvalitním provedení však využití této metody při participativním rozhodování směřuje k nalezení lépe prodiskutovaného řešení, které je snáze přijímáno sociálními aktéry (a to dokonce i těmi, kdo jsou vůči němu v opozici, srov. Fritsch a Newig (2012)) a k následné snazší implementaci. Pokud byla část rozhodnutí, řešení přijata/vytvořena někde jinde a pouze předložena ke schválení, snižuje takový postup šanci na přijetí ze strany veřejnosti. AA Ize také úspěšně využít při úsilí o co nejvyšší zapojení občanů do politického a veřejného života společnosti. 


\begin{tabular}{|c|c|}
\hline \multicolumn{2}{|c|}{ Cíle metody AA } \\
\hline Základní úroveň & Rozšířená úroveň \\
\hline $\begin{array}{l}\text { zmapování sítě aktérů } \\
\text { • } \quad \text { identifikace aktérů } \\
\text { vytipování hlavních a vedlejších aktérů } \\
\text { v daném případě, určení jejich rolí } \\
\text { - charakteristika aktérů (popis vlastností } \\
\text { jednotlivých aktérů ve vztahu k pro- } \\
\text { blému) } \\
\text { optimalizace vztahů aktérů mezi sebou i vzhle- } \\
\text { dem k řešenému problému } \\
\text { předcházení konfliktům, hledání řešení optimál- } \\
\text { ních pro různé aktéry a jejich sítě } \\
\text { následné zapojení aktérů do implementace } \\
\text { opatření (na základě jejich zapojení do diskuse o } \\
\text { něm) }\end{array}$ & $\begin{array}{l}\text { analýza sociálních sítí: popis a analýza skrytých } \\
\text { sil, které mohou ovlivňovat rozhodovací procesy } \\
\text { nebo jim bránit } \\
\text { hledání souvislostí mezi charakteristikami ak- } \\
\text { térů, sítí a procesy komunikace, jejich výsledky - } \\
\text { > obecná doporučení pro uspořádání vztahů a } \\
\text { vedení procesů vyjednávání } \\
\text { popis a zkoumání problémů (udržitelného) roz- } \\
\text { voje jako společenských jevů s možnostmi apli- } \\
\text { kace relevantních metod (např. analýza sociál- } \\
\text { ního kapitálu's návrhy jeho posilování v praxi) } \\
\text { shromažd'ování a prohlubování obecného po- } \\
\text { znání v oblasti participativního rozhodování }\end{array}$ \\
\hline
\end{tabular}

\section{Kde je možno využít}

Analýza aktérů je jedním z možných přístupů, které lze využít pro podporu participativního rozhodování. Je užitečná při plánování efektivní občanské participace, například při řešení rozvojových otázek na místní úrovni - př́kladem může být úmysl vyhlásit novou chráněnou oblast, realizovat nový developerský projekt (silnice, obytný komplex, komerční zástavba) či jiný podnikatelský záměr, nebo se dohodnout na strategii udržitelného rozvoje určitého území. Kromě orientace na budoucí vývoj a řešení konkrétního zadání nebo projektu je však možné využít analýzu aktérů také k popisu a evaluaci již uskutečněných rozhodovacích procesů, což pak vede ke kumulaci zkušeností. V neposlední řadě je možné analyzovat a porovnávat více prípadů $\mathrm{s}$ cílem přispět $\mathrm{k}$ hlubšímu poznání participativních způsobů správy věcí veřejných.

\footnotetext{
${ }^{1}$ Sociálním kapitálem rozumíme vztahy založené na dobré zkušenosti a důvěre, vztahy, které lze v př́ípadě potřeby aktivně využít, stejně jako jiné formy kapitálu (ekonomický, kulturní) je produktivní:

Čím větši je sociální kapitál, tím více toho skupina může dosáhnout (Putnam, 2000). Může se zabývat i cíli, které, by jinak byly mimo její dosah:Skupina, uvnitř které jsou vztahy založené na vysoké míre důvěry a spolehlivosti je schopna uskutečnit mnohem více cílů než srovnatelná skupina bez obdobné úrovně důvěry a spolehlivosti. (Coleman, 1988).
} 
Užití metodiky může ale také např́iklad přispět ke SWOT analýze a $\mathrm{k}$ analýze rizik určitého projektu a může se tak stát součástí kvalitně zpracované projektové žádosti v oblasti veřejné politiky. $V$ každém $z$ těchto způsobů využití metodiky je ovšem potřeba pracovat $s$ jejími nástroji pružně - to znamená adaptovat je podle konkrétního cíle (zajištění spolupráce, předcházení konfliktu, nastavení dlouhodobých vztahů atd.) a specifických místních podmínek.

Metodika je v praxi využitelná v těchto případech:

\section{Možnosti AA: oblast možného uplatnění metodiky}

\begin{tabular}{l}
\hline Základni (praktická) úroveň popisu \\
\hline Obecně v rozhodovacích procesech - tam, kde \\
mohou střetnout protichůdné zájmy: \\
- při zavádění zásadní inovace a plánování \\
(např. urbanismus, ochrana prírody, pro- \\
gramy rozvojové pomoci v zemích třetího \\
světa, atd.), \\
při hledání aktérů spolupráce v mezioboro- \\
vých projektech či v rámci dialogu mezi ex- \\
perty a laiky,
\end{tabular}

Na různých prostorových škálách a úrovních obecnosti problému:

- na národní úrovni: záležitosti veřejné nebo úzce zaměřené (příprava specializované strategie) $v$ oblasti veřejné politiky

- v konkrétních (regionálních či místních) otázkách státní správy a samosprávy (např. ochrana prírody, dopravní plánování, urbanismus, apod.) i komerční sféry (př́prava podnikatelských záměrů a jejich konzultace s aktéry)

- $\quad v$ obecných, tematicky definovaných případech (např. aktéri diskusí o klimatické změně).
Rozšírená úroveň

Zkoumání sociálního kapitálu prostřednictvím metod sitové analýzy

Rozvíjení postupů kvalitativního výzkumu, např. formou př́padových studií

- zjišt́ování vztahů aktérů v případových studiích (události z historie, zkoumání vlivu společenského prostředí na objektivní jevy apod.)

- srovnávací analýzy při zkoumání vývoje společenského prostředí a/nebo dané kauzy $v$ různých společenských kontextech

Shromažd'ování zkušeností se zapojením aktérů (napríklad v rámci prípadových studií) a postupné budování teorie participativního rozhodování.

Jako pedagogický nástroj ve vysokoškolské výuce pro učení založeném na řešení praktických problémů v kontextu reálných situací (Dlouhá, Huisingh, Barton, 2013; Dlouhá, 2014)

\section{Kde její využité není vhodné}

Pro analýzu aktérů je třeba na začátku vymezit hodnotovou škálu, tedy například určit „žádoucí směřování" (např. k udržitelnému rozvoji) a "negativní vztah“ k určitému záměru (např. k realizaci projektu) atd. $\vee$ př́padech, kde taková hodnotová orientace možná není, a mělo by jít pouze o objektivní popis společenského prostředí, se využití metodiky AA nedoporučuje - není možné vytvořit orientační body, ve vztahu k nimž by se jednotliví aktéři popisovali (též jejich vzájemné vztahy jsou bez tohoto vodítka ambivalentní). 


\section{Pro koho}

Jak již bylo řečeno, metodika má v praxi sloužit pro účely participativního rozhodování v otázkách veřejného zájmu a udržitelného rozvoje. Hlavní prostor pro uplatnění analýzy aktérů je na místní a regionální úrovni při řešení konkrétních rozvojových projektů, jak je tomu i v zahraničí (Zimmermann \& Maennling, 2007). Může být tedy využita vedoucími úředníky či politiky při tvorbě a prosazování strategií, státní správou a samosprávou při realizaci větších projektů (stavba nemocnice, výchovného ústavu) ale též nevládními organizacemi například při plánovaní kampaní a vzdělávacích aktivit, a samozřejmě i komerční sférou pro konzultaci podnikatelských záměrů s dotčenými aktéry.

Kým a pro koho- do AA jsou různou formou zapojeni a/nebo využívají jejích výsledků (aktéři $A A)$ :

\begin{tabular}{|c|c|}
\hline Základní (praktická) úroveň popisu & Rozšířená úroveň \\
\hline $\begin{array}{l}\text { - veřejný rozhodovatel (politici, vedoucí úřed- } \\
\text { níci, atd.), } \\
\text { - odborný zpracovatel/konzultant (ten, kdo } \\
\text { navrhuje nějaký proces: mǔže to být NNO, } \\
\text { konzultační firma, apod.), } \\
\text { - další zájemci (různé NNO, a všichni, kdo usi- } \\
\text { lují o konkrétní změny v budoucnosti (pro- } \\
\text { jekty, programy...) }\end{array}$ & $\begin{array}{l}\text { - } \quad \text { think-tanky, expertní a konzultační firmy } \\
\text { - } \quad \text { vědci analyzující príípadové studie nebo (v } \\
\text { obecnější rovině) mapující společenské } \\
\text { prostředí z hlediska určitého politického } \\
\text { směřování. } \\
\text { - } \quad \text { vysokoškolští pedagogové v oblasti veřejné } \\
\text { a sociální politiky, životního prostředí, plá- } \\
\text { nování (architektura, urbanismus, doprava) }\end{array}$ \\
\hline $\begin{array}{l}\text { Zadává ji většinou jeden aktér (politik, úředník), } \\
\text { vede však k rovnému a transparentnímu zapo- } \\
\text { jení dalších aktérů, například odborníků, do roz- } \\
\text { hodování. }\end{array}$ & $\begin{array}{l}\text { Analýzu provádí úzká skupina odborníků, avšak } \\
\text { do procesu analýzy jsou zapojeni aktéři mimo } \\
\text { rámec této odborné sféry - účastní se jí v růz- } \\
\text { ných rolích. }\end{array}$ \\
\hline
\end{tabular}

\section{Předpoklady realizace}

Základní nezbytností pro realizaci AA je především určitá expertiza a zkušenost s facilitací procesů vyjednávání; kromě toho je nutný určitý časový prostor pro pochopení situace a vedení dialogu. Nejprve je ovšem nutné jasně pojmenovat a vymezit konkrétní problém, ke kterému se bude vázat výzkumná otázka a identifikace aktérů. Zásadní je dále přístup $\mathrm{k}$ informacím a ochota aktérů, zejména těch klíčových, je poskytovat, aby bylo možné zmapovat situaci a zahrnout přitom celou škálu pohledů a názorů. Je třeba mít možnost získané informace dále ověřovat, aby byly závěry věrohodné. $Z$ toho důvodu je také zapotřebí zejména u popisu aktérů z hlediska jejich hodnot a cílu kombinovat pohled více hodnotitelů. 


\section{Potřeby a nároky provádění analýzy aktérů}

\section{Kapacity}

personální (v závislosti na rozsahu analýzy - upřesnění rolí viz kapitola Ekonomické přínosy a potřeby při analýze aktérů):

- koordinátor (znalý místního prostředí)

- tým posuzovatelů (znalých místních vazeb, ideálně z řad místních obyvatel a zároveň zástupců různých aktérů)

- odborný konzultant

- facilitátor

materiální:

- náklady na personální zajištění

- náklady na sběr a vyhodnocení informací: realizaci a vyhodnocení rozhovorů (př́padně ankety, či dotazníkového šetření) a dalších analytických postupů

- umožňující organizaci důležitých aktivit, např. setkání aktérů a př́padné veřejné projednání (ne vždy je třeba použít všechny techniky)

časový prostor:

- přiměřeně zajištěná možnost pro realizátora analýzy se pohybovat v prostředí jako pozorovatel, setkávat se s aktéry, vést rozhovory atd.

Odbornost:

- znalost postupu analýzy (této metodiky) a případně povědomí o odborné diskusi v této oblasti (možno využít zde uvedených odkazů)

- znalost cílú analýzy a prostředí, ve kterém se bude analýza provádět

- znalost facilitačních postupů (v případě veřejného projednání)

- pro rozšiřenou (výzkumnou) úroveň: znalost empirických metod i teorií, hypotéz a dosavadní poznání podložené výzkumem

Dovednosti

- zkušenost s jednáním s různorodými skupinami obyvatel, umění komunikace

- umění využít místní podmínky, zkušenosti a znalosti; reflektovat je i aktivně přispívat externím know-how

- schopnost zapojení do vztahů a využití jejich potenciálu, ale současně odstup a nezávislost

Vztahy a komunikační mechanismy

- znalost místních vazeb a prostředků i zvyklostí komunikace; jejich využití a podpora

Hodnotové předpoklady:

- nezávislost na cílech vyjednávání (pozice realizátora není vnímána kontroverzně, je důvěryhodný)

Přístup k ověřeným informacím:

- zdroje informací (ochota aktérů je poskytovat; alternativní zdroje = možnost ověřovat) 


\section{Ekonomické prínosy a potřeby při analýze aktérů}

Ekonomický prospěch z využití metodiky nelze přímo vyčíslit. Fáze její aplikace přináší v rámci rozhodování dodatečné náklady (viz dále rozpis potřebných rolí a pracovníků); př́nosy pak lze očekávat až ve fázi implementace strategie nebo projektu, k nimž se analýza vztahovala, a to v dlouhodobém horizontu. $V$ analýze aktérů se mají předem vyřešit rozdílné názory zúčastněných stran a sporné body jejich spolupráce - výsledkem je pak hladší průběh implementace strategie nebo realizace projektu, jak je patrné z obrázku 1. Přínosem využití metodiky má být vytvoření transparentního prostředí pro rozhodování a budování vztahů založených na vzájemné důvěře, tedy vzrůst sociálního kapitálu, nikoli ekonomického. Úroveň sociálního kapitálu však úzce souvisí s ekonomickým růstem, protože „sítě, normy a důvěra, to vše může přispívat k efektivnímu fungování trhů. Sociální kapitál je spojený s ekonomickou situací, a to jak na úrovni individuální (např. př́ijem jednotlivce), tak na úrovni společenské (hospodářská situace v regionu - výše mezd, nezaměstnanost atp.)“ (Stachová et al, 2009).

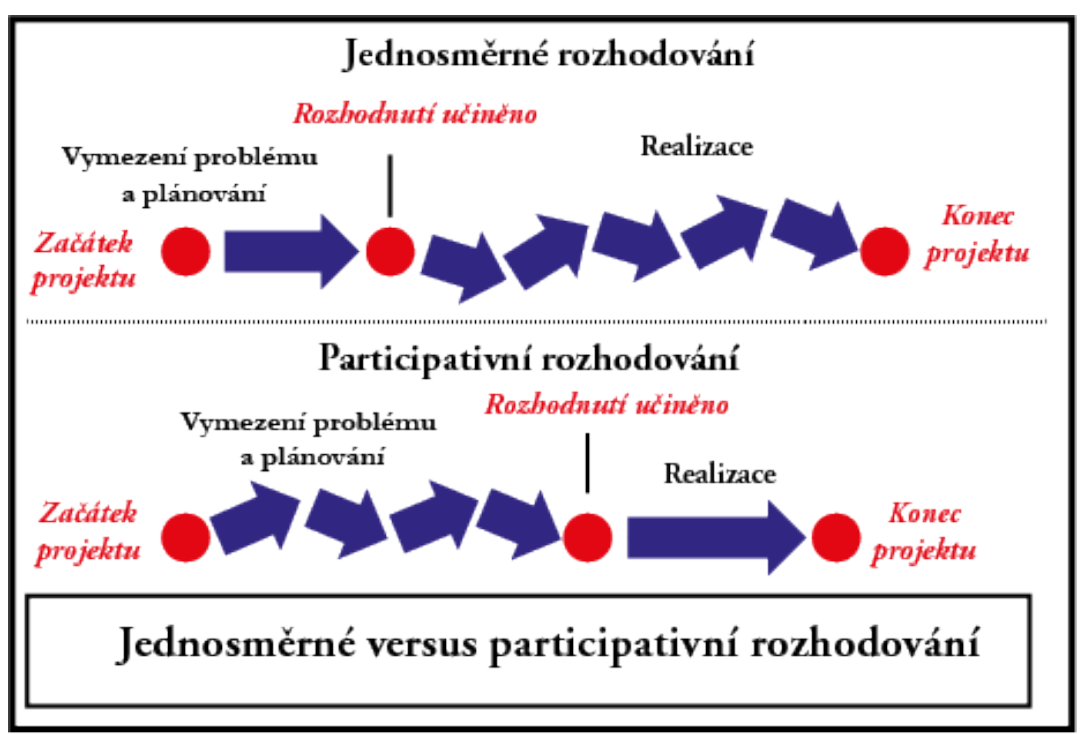

Obrázek 1. Rozdíl mezi jednosměrným a participativním rozhodováním z hlediska hladkosti průběhu implementace rozhodnutí (fáze realizace). Zdroj: (HarmoniCOP Team, 2005).

Náklady AA souvisí s těmito body:

Hloubka analýzy: analýzu aktérů Ize pojmout různě v závislosti na cílech analýzy a zdrojích, které jsou pro její realizaci k dispozici: od méně náročné formy brainstormingu po podrobný terénní sociologický výzkum. Ve všech př́padech je ale zapotřebí věnovat dostatek pozornosti jednotlivým krokům, od vymezení problému, přes identifikaci aktérů a práci s informacemi až po interpretaci zjištění, byt́ jejich konkrétní naplnění se bude $v$ jednotlivých př́padech lišit. Je také zapotřebí otevřeně uvést, kdo a za jakým účelem ( $v$ jaké roli) analýzu zpracoval, jak spolehlivé byly zdroje informací a zda kdo z aktérů do analýzy přispěl svým úhlem pohledu.

Rozsah analýzy: dle závažnosti a šiře problému bude zapotř̌ebí realizátorů $A A$ v různých rolích. Podle rozsahu analýzy je ovšem může zastávat jedna osoba nebo více - např. Ize pro každou roli vyčlenit jednoho pracovníka. Tyto role jsou následující: 
V první řadě je třeba určit koordinátora analýzy, který dohlíži nad její realizací. Koordinátor je obeznámen s postupem analýzy, je schopný komunikovat s lidmi a v př́padě střetu zájmů není vnímán jako kontroverzní osoba. Jako vstupní informace může pro koordinátora sloužit tato metodika, pokud ale nemá vlastní zkušenost s metodami sociologického nebo antropologického výzkumu, měl by být do realizace analýzy zapojen také odborný konzultant.

Odborný konzultant je osoba, která má zkušenost s postupy aplikovaného výzkumu a konkrétně s realizací analýzy aktérů; v praxi pomáhá dohližet nad a) korektním uplatněním analýzy a b) vypomáhá v prípadě netriviálních úkonů, jako např. při analýze sítě a interpretaci vztahů mezi aktéry. Analýza aktérů může sloužit jako nástroj akčního výzkumu, kdy roli expertů přebírají poučení odborníci z praxe. Zapojení vědeckého pracovníka tedy není nezbytnou podmínkou, nicméně je třeba dodržet zásady zodpovědného nakládání s informacemi tak, aby nedocházelo k systematickému zkreslování (at již zamýšlenému či nikoliv) závěrů, viz kapitola Charakteristika aktérů.

Pro výběr aktérů je u větších kauz vhodné zapojit tým posuzovatelů, který spolupracuje na vstupním vymezení aktérů. Stejně tak pro vyhodnocení charakteristik aktérů je, kromě kombinování různých zdrojů informací, vhodné zapojit alespoň tři nezávislé posuzovatele, kteří mají vhled do problému. Vhodné je do procesu identifikace aktérů zapojit přímo místní obyvatele jako znalce prostředí a vztahů, ideálně zástupce různých názorových skupin tak, aby seznam aktérů byl úplný a nestranil té či oné straně.

V prípadě propojení analýzy aktérů s participativním rozhodovacím procesem je navíc vhodné angažovat odborníka na komunikaci a vedení skupinových diskusí (facilitátora) a zajistit účast dalších rolí, viz kapitola Management participačního procesu - jaké pozice a role potřebujeme v Metodice participace iniciativy PAKT (PAKT, 2015b).

Odpovědný přistup k analýze vyžaduje získání informací od všech zájmových skupin a/nebo stran potenciálního konfliktu a v prípadě participace i jejich následné zapojení do rozhodování.

\section{Možné výsledky, prínosy a rizika}

Výsledky a př́nosy závisí na možnostech metody AA jako takové a cílech, s nimiž je použita; diskusi přínosů viz též kapitola Ekonomické aspekty. Pro jejich dosažení je nezbytné efektivně předcházet rizikům.

\begin{tabular}{|c|c|}
\hline Možné výsledky & Možná rizika \\
\hline $\begin{array}{l}\text { Popis aktérů, jejich charakteristik a zájmů } \\
\text { Popis rolí, výběr hlavních a vedlejších aktérů } \\
\text { Mapa aktérů } \\
\text { Mapa vztahů mezi nimi s ohledem na zvolené cha- } \\
\text { rakteristiky (moc, důvěryhodnost, komunikace, } \\
\text { know-how, angažovanost, atd.) } \\
\text { Doporučení praktických opatření (kdy a v jaké formě } \\
\text { aktéry zapojovat, výchozí body pro hledání řešení) } \\
\text { Analýza sítě aktérů } \\
\text { Srovnání různých případů: způsobů rozhodování ve } \\
\text { věcech veřejných }\end{array}$ & $\begin{array}{l}\text { Nevyvážení (malá či velká) osobní angažova- } \\
\text { nost na problému - neschopnost získat odstup } \\
\text { Zkreslení závěrů nebo nejasné závěry (nedosta- } \\
\text { tečná koordinovanost, neověřené informace) } \\
\text { Podcenění časových či kapacitních nároků a ne- } \\
\text { uspokojivé výsledky } \\
\text { Obtí̌̌nost založení vztahů důvěry ve skepticky } \\
\text { naladěném či nepřátelském prostředí } \\
\text { Snaha řešit dlouhodobý či hluboký konflikt nea- } \\
\text { dekvátními prostředky }\end{array}$ \\
\hline
\end{tabular}




\begin{tabular}{|c|c|}
\hline Přínosy & Rizika \\
\hline $\begin{array}{l}\text { Transparentnost procesů rozhodování } \\
\text { Posílení důvěry a zájmu o věci veřejné (budování so- } \\
\text { ciálního kapitálu) } \\
\text { Předcházení konfliktním situacím } \\
\text { Snadnější implementace projektů či strategií } \\
\text { Osvětlení sociálních vztahů a jejich role pro daný pří- } \\
\text { pad } \\
\text { Budování poznání v oblasti participace, diskuse nad } \\
\text { očekáváními a výhradami vǔči zapojování veřejnosti } \\
\text { do rozhodovacích procesů: } \\
\text { - zvyšuje kvalitu přijímaných rozhodnutí tím, že do } \\
\text { nich vnáší znalosti místních aktérů (Steele 2001; } \\
\text { Pellizoni 2003) } \\
\text { - zlepšuje přijetí rozhodnutí a tím usnadňuje jeho } \\
\text { implementaci (Macnaghten \& Jacobs 1997) } \\
\text { - díky tomu vede k lepším řešením s ohledem na žp } \\
\text { než hierarchické top-down řízení (Newig 2007) } \\
\text { - změna mocenské struktury (politikové náchyl- } \\
\text { nější k hledání politického zisku a podléhající lob- } \\
\text { bystickým tlakům), zlepšení informovanosti a so- } \\
\text { ciální učení vedou k ekologičtějším rozhodnutím } \\
\text { (Fritsch \& Newig, 2012) } \\
\text { v otázkách životního prostředí je vnímána jako } \\
\text { přístup, který je schopen řešit i dlouhodobě pre- } \\
\text { trvávající problémy (Hogl et al., 2012, p. 2), které } \\
\text { nejsou dobře spravovány a nacházejí se ve špat- } \\
\text { ném nebo zhoršujícím se stavu a vyžadují oka- } \\
\text { mžitou pozornost (OECD, 2008, p. 24). }\end{array}$ & $\begin{array}{l}\text { Ztráta důvěry (nedostatečná satisfakce účast- } \\
\text { níků) } \\
\text { Nedostatečná podpora rozhodovatelů (nezájem } \\
\text { o proces a jeho výsledky) } \\
\text { Chybné či nedostatečné uplatnění výsledků zís- } \\
\text { kaných AA a následná nedůvěra v jakoukoli } \\
\text { formu participace } \\
\text { Skeptická stanoviska vůči zapojování veřejnosti } \\
\text { do rozhodovacích procesů: } \\
\text { zájmy místních obyvatel často představují } \\
\text { jiné, krátkodobější cíle, než udržitelný rozvoj } \\
\text { (Kastens \& Newig 2007) } \\
\text { může vést k napadení vysokých ekologických } \\
\text { standardů (Layzer, 2008). }\end{array}$ \\
\hline
\end{tabular}

Pro využití analýzy aktérů v rámci participativního rozhodování obecně platí, že úspěšnost je závislá na nastavení procesu (umění organizátorů), kdy je třeba vyvážit potřebu nalezení konsensu na straně jedné, a možnosti zapojení aktérů na straně druhé. Je tedy nutné brát do úvahy základní rizika, ke kterým patří a) nedostatečná koordinovanost celého procesu, b) nedostatečná satisfakce účastníků a c) negativní postoj politické reprezentace (Bernard, 2015). 


\section{Postup analýzy aktérů}

Úroveň formalizace postupu se při využití metody analýzy aktérů může lišit: od rigorózně uplatňujícího ověřené přístupy po spíše intuitivně rízený proces, dodržující však zásady spolehlivosti (zodpovědného, nemanipulativního nakládání s ověřenými informacemi). Dílčí fáze postupu jsou ve všech prípadech shodně prítomny a mohou tedy být shrnuty do šesti základních kroků tvořících metodický rámec AA (Obr. 2). Jednotlivé kroky jsou detailněji popsány v následujících sekcích.

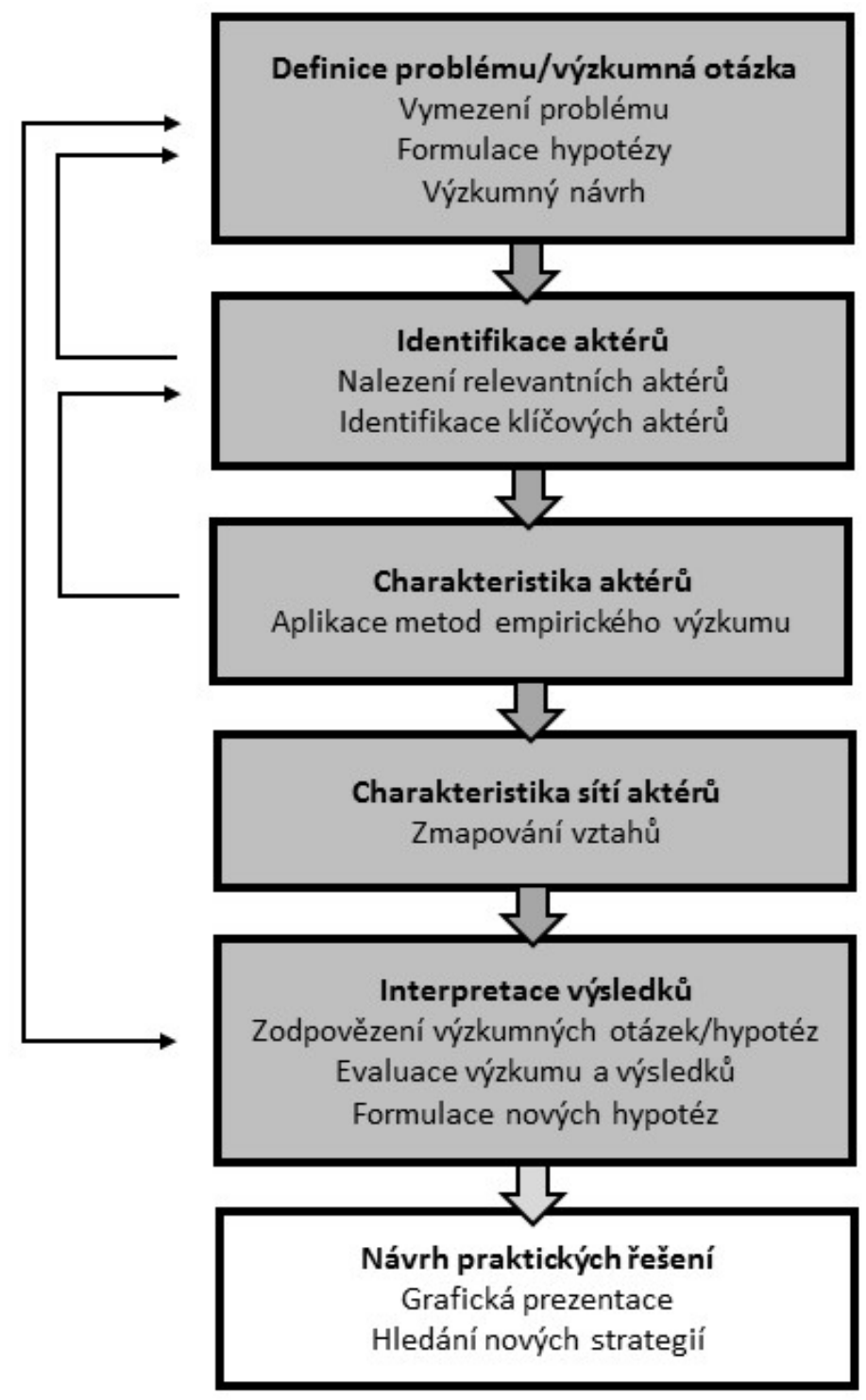

Obr. 2: Metodický rámec Analýzy aktérů znázorňující jednotlivé kroky postupu (modifikováno dle Newig, 2012a, Burandt, 2015). Šipky vlevo poukazují na potřebnost vracet se k některým krokům a upravovat je v průběhu celého procesu v závislosti na dílčích výsledcích. 


\section{Jednotlivé kroky AA}

\section{Definice problému/výzkumná otázka}

První krok metody analýzy aktérů zahrnuje vymezení problému, formulaci hypotézy a návrh (výzkumného) postupu. $V$ této fázi je třeba si položit otázky, na které má $A A$ metodicky nalézt odpovědi. Vlastní definice problému pak úzce souvisí s postoji aktérů, ke kterým se problém vztahuje. Součástí popisu problému by tedy měl být také popis hodnot a postojů, který může poukázat na společné či potenciálně konfliktní postoje zainteresovaných aktérů. Tento proces může být poměrně časově náročný, protože je třeba dojít ke skutečně inkluzivnímu vymezení zkoumaného pole. Finální definice problému je tedy $v$ některých případech ještě upravována a dopracována až po provedení interpretace výsledků (viz Obr. 2).

Př́klad definice problému: AA jako podklad pro strategický plán rozvoje obce

Hranice analýzy jsou dány konkrétní obcí a aktéry, kteří ovlivňují možnosti jejího rozvoje

Otázky pro AA při přípravě strategického rámce rozvoje obce:

- Jaké jsou mezi obyvateli obce představy o jejím budoucím rozvoji?

- Jaké vidí cíle a priority budoucího rozvoje obce?

- Co považují (občané/aktéři) za přednosti a za nedostatky života v obci?

- Jaké vnímají ohrožení a naopak potenciál pro rozvoj obce?

- Existují zde sociální aktéři, skupiny sdružující se kolem specifického pohledu na rozvoj obce, rozdílné názorové skupiny?

- Dochází mezi nimi ke konfliktům?

- Co je př́činou prípadného střetu zájmů?

- Kde je prostor pro spolupráci občanů?

- Existují vhodné podmínky k veřejnému projednání cílů a priorit rozvoje obce?

Jiným př́kladem může být srovnávací analýza případových studií, která usiluje o reflexi teoretických předpokladů o participaci. Hranice analýzy jsou dány př́pady kauz místního nebo regionálního udržitelného rozvoje, kdy vstupují do hry různé společenské skupiny.

Otázky AA pro porovnání príipadových studií:

- Existují nějaké shodné rysy v případech místních kauz udržitelného rozvoje v ČR?

- Jací aktéři a $v$ jakých rolích se $v$ těchto prípadech vyskytují?

- Čím jsou charakterizovány úspěšné príípady, kdy se daří formulovat sdílenou vizi udržitelného rozvoje (s pozitivním dopadem na vztahy a životní prostředí)?

- Jaké jsou společné charakteristiky prípadů, kdy se nedaří nalézt řešení (negativní dopad na vztahy mezi aktéry)?

- Jaké jsou podmínky úspěšného regionálního rozvoje s ohledem na procesy komunikace mezi účastníky?

- Přispívá zapojení místních obyvatel ke kvalitě přijímaných rozhodnutí s ohledem na životní prostředí? 


\section{Identifikace aktérů}

Druhým krokem je nalezení aktérů a následné určení klíčových aktérů. Cílem tohoto kroku je vytvoření seznamu všech hráčů, kteří mají vztah k určenému problému, a výběr těch nejdůležitějších.

Aktérem dle předchozí definice rozumíme skupinu lidí, kteří mají společné zájmy a spolupracují na dosažení určitého cíle. Může se jednat o organizace jakékoli velikosti (od malých po velké) a formálního uspořádání (od organizovaných po semi-organizované skupiny lidí, kteří konají v rámci společného zájmu). Pro dosažení skutečně inkluzivního seznamu aktérů, který zahrne všechny, kdo mají k problému nějaký vztah, Ize za aktéra pokládat též neorganizovanou veřejnost. I když je obtižnější takového aktéra vymezit a charakterizovat, protože nemusí vytvářet konzistentní skupinu s jasně formulovaným postojem, může hrát v rozhodovacím procesu významnou roli. Navíc je tak možno podpořit zájem a zapojení běžných občanů do záležitostí, které se dotýkají jejich životů, což je jedním z důležitých cílů participace (je totiž zapotřebí usilovat o aktivizaci i těch, kdo by jinak zůstali pasivní). V konkrétních prípadech regionálního rozvoje se veřejností zpravidla myslí obecně místní obyvatelé, ale vzhledem $\mathrm{k}$ řešené otázce se Ize blíže zaměřit např. na rodiny s dětmi, seniory, ženy, děti a mládež, či další skupiny jako jsou lidé s omezenou pohyblivostí, etnické menšiny, turisté, apod.

Pro výběr jednotlivých aktérů a vzhledem $\mathrm{k}$ jejich zájmům existují různé metodické přistupy, například tzv. „,Vzorec STEEP“ (STEEP-formula), který zohledňuje Sociální, Technologické, Environmentální, Ekonomické a Politické sféry zájmu (Lynch, 2012; Burandt, 2015). Zaručuje, že vybraní aktéři budou poměrně rovnoměrně reprezentovat všechny tyto oblasti. Samotné určení aktérů zpravidla probíhá na základě studia dokumentů (výzkumné články, veřejná media, TV spoty, atp.) a rozhovorů s těmi, kdo mají do situace významný osobní vhled.

Standardním postupem pro vytvoření seznamu aktérů je technika tzv. nabalování nebo také sněhové koule, kdy začínáme s užším seznamem aktérů vytvořeným na základě vstupní znalosti problému a postupně tento seznam rozšiřujeme díky rozhovorům se samotnými aktéry, místními občany či s odborníky zasvěcenými do situace. Pokračujeme až do bodu, kdy se začínají doporučení na další aktéry opakovat a žádní další významní aktéři již nepřibývají.

Kromě této techniky nabízí Enserink et al (2010) k identifikaci aktérů kombinaci postupů: např. přístup silného imperativu: „Kdo má zájem na řešení daného problému nebo kdo bude pocitovat jeho důsledky?“, dále již zmíněný postup vymezení aktérů na základě demografických charakteristik (věk, pohlaví, dosažené vzdělání, profese, apod.); poziční př́stup (kdo je v pozici s vlivem na rozhodování); participační kritérium (kdo se již nějakým způsobem zapojuje do aktivit souvisejících s řešením problému; princip identifikace názorových leaderů (ti, kdo mají schopnost ovlivňovat postoje ostatních). Nakonec je třeba konfrontovat seznam aktérů s otázkou: Kdo nebo co, př́mo či nepř́mo ovlivňuje popsanou skupinu aktérů a její strukturu? $\vee$ úvahu je přitom zapotřebí brát jak aktéry či faktory uvnitř, tak vně navrženého systému (Enserink et al, 2010: 85), například místní tradice nebo pravidla a zákony působící na vyšší úrovni. U otázky aktérů vstupujících do rozhodování a o strategickém plánu rozvoje obce v rekreační oblasti národního parku pak Ize uvažovat krom místních obyvatel, podnikatelů, chalupárưu, turistů, samotného národního parku, atd., též např. o politicích, kteří svými rozhodnutími ovlivňují chod národního parku a situaci v obci, o fungování a rozhodnutích stavebního úřadu, o historii vytváření vztahů mezi místními obyvateli a jejich propojení s okolní prírodou, apod..

Pro urychlení procesu výběru (a charakteristiky) hlavních aktérů je také možné pracovat ve skupině odborníků či přímo zástupců různých aktérů a využít řízené skupinové diskuse (focus group). Tento 
přistup pomáhá šetřit čas, protože znalci místního prostředí ve vzájemné diskusi určí, dík znalosti lokálních vazeb, široké spektrum aktérů a pokud ve skupině pracují zástupci různých zájmových skupin, pomohou vzájemně ohlídat nominaci opravdu všech dotčených stran. Otázky, které si lze v této souvislosti klást mohou být např. následující:

- Na koho byste se obrátili, pokud byste se potřebovali o tomto problému dozvědět více?

- Kdo určuje pravidla při řešení tohoto problému?

- Kdo disponuje znalostmi, odborností nebo jinými důležitými zdroji pro řešení tohoto problému?

- Kdo má řadu vazeb na ostatní subjekty dotčené řešeným problémem? (Zimmermann, Maennling, 2007: 12)

nebo

- „Pro koho má projekt největší potenciální užitek?

- Koho může projekt potenciálně ohrozit?

- Kdo může být nejvíc pasivní a nejvíc aktivní skupina?

- Je nebo může být mezi některými skupinami konflikt?

- Jaké mají skupiny specifické potřeby z hlediska komunikace (typ médií, vhodné dny a čas pro setkání apod.)?

- Jsou ve skupinách výrazní jednotlivci (neformální lídři)?“" (PAKT, 2015b: 35)

Aktéři mohou být také rozlišeni dle svých postojů vůči danému problému, a to jako „rozdělovači“, kteří mohou zvýšit konflikt, či "spojovači", jejichž role je spiše v propojování názorů a mediaci napětí (Zimmermann, Maennling, 2007: 12).

Proces identifikace aktérů zůstává otevřený i v dalším postupu analýzy, jde však o to, abychom jich většinu odhalili již v tomto bodě a dále se mohli soustředit na rozpoznání těch klíčových. Zvláště v príipadě konfliktních situací je zapotřebí nevylučovat žádnou ze stran sporu a pro rozhovory a poskytnutí informací kontraktovat všechny názorové skupiny. Výsledkem v tomto okamžiku je široký seznam aktérů.

\section{Určení významných aktérů}

K určení kličových aktérů Ize poté dospět pomocí sady kritérií (metodou hodnocení zv. multi criteria assessment). Jinými slovy zde bereme do úvahy několik ( $z$ hlediska řešení problému důležitých) vlastností aktérů a zároveň hledáme takové, u kterých jsou tyto vlastnosti nejsilnější. Mezi tyto důležité vlastnosti patří např. role a legitimita aktéra, tedy míra jeho uznání dalšími aktéry (legitimita může být institucionální či právně ukotvená - poskytující např. právo veta, - ale také daná tím, že aktér reprezentuje více hlasů, určitou část skupiny, část veřejnosti), zdroje a odpovědnost (znalosti a schopnosti, expertíza, ale také materiální zdroje, které umožňují klíčovému aktérovi mít zásadní vliv na řešený problém, nebo kontrola nad př́stupem k takovým zdrojům) a vzájemné vztahy (množství a kvalita vztahů k ostatním zainteresovaným aktérům), viz Tabulka 1. Klíčoví aktéři by měli mít silnou pozici alespoň ve dvou z těchto oblastí, jak ukazuje Obrázek 3 (cf. Crosby, 1991; Brugha, Varvasovszky in Newig 2012a; Zimmermann and Maennling, 2007). 
Tabulka 1. Postup identifikace klíčových aktérů (multi criteria assessment) (dle Zimmermann, Maennling, 2007)

\begin{tabular}{|c|c|c|c|c|}
\hline \multirow{2}{*}{$\begin{array}{l}\text { Potenciální klíčový } \\
\text { aktér ve vztahu k } \\
\text { identifikovanému } \\
\text { problému }\end{array}$} & \multicolumn{3}{|c|}{ Pozice a základní úloha aktéra } & \multirow{2}{*}{$\begin{array}{l}\text { Poznámky } \\
\text { ohledně role } \\
\text { a zapojení } \\
\text { aktéra }\end{array}$} \\
\hline & $\begin{array}{l}\text { ROLE A LEGITI- } \\
\text { MITA }\end{array}$ & $\begin{array}{l}\text { ZDROJE A ODPO- } \\
\text { VĚDNOST }\end{array}$ & $\begin{array}{l}\text { VZÁJEMNÉ } \\
\text { VZTAHY }\end{array}$ & \\
\hline \multicolumn{5}{|l|}{ Aktér 1} \\
\hline \multicolumn{5}{|l|}{ Aktér 2} \\
\hline Aktér 3 & & & & \\
\hline
\end{tabular}

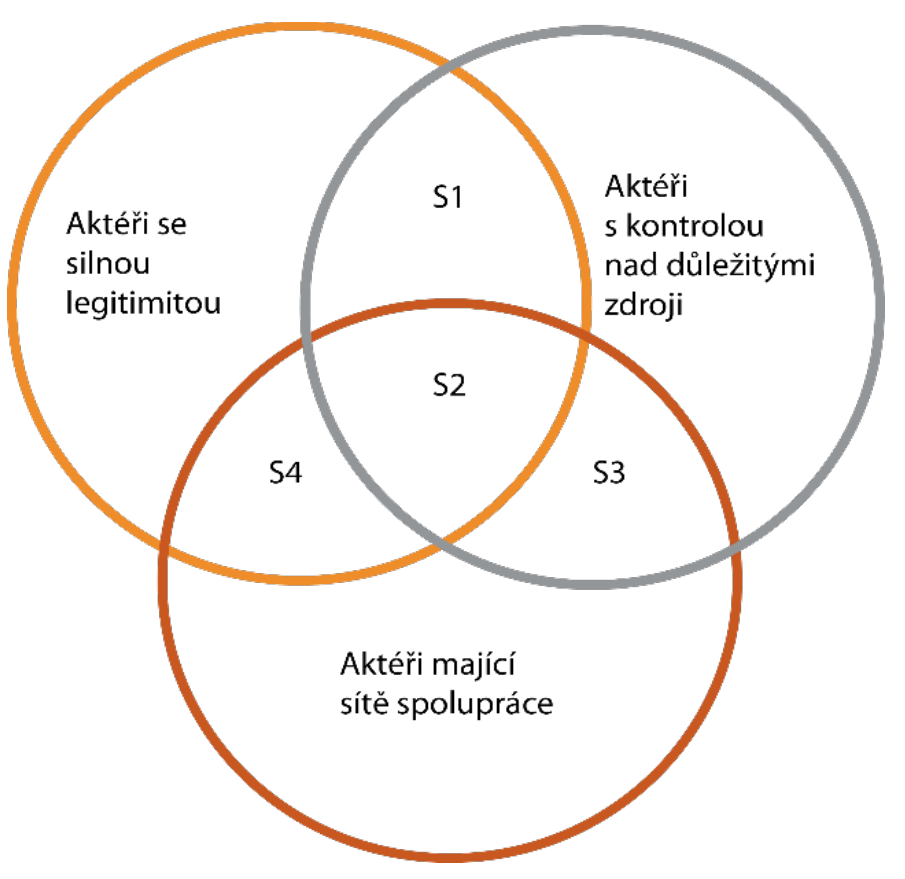

Obrázek 3: Určení klíčových aktérů S1 - S4, podle (Zimmermann, Maennling, 2007)

Po identifikaci aktérů je $v$ mnoha prípadech třeba revidovat první krok a př́padně upravit definici problému (viz. Obr. 2). Jde především o to, aby byly zřetelně vymezeny hranice zkoumaného jevu, a tedy i sítě aktérů. Je třeba vyvážit snahu o zahrnutí co nejvyššího množství aktérů s efektivitou analýzy. Na jedné straně tedy nesmíme nikoho opomenout, na straně druhé však musíme vymezit problém a sít aktérů tak, abychom se v ní orientovali a dokázali s ní rozumně pracovat. 
Výběr aktérů je proto možné rozdělit do více kroků²:

„1. V prvním kroku dojde k vytvoření seznamu všech možných konzultovaných subjektů. Tento seznam může být velmi dlouhý a pro inspiraci lze např́ílad využít DataKO nebo databázi neziskových organizací na Portálu veřejné správy či rejstř́iky a seznamy, ve kterých jsou různé organizace vedené na př́slušných ministerstvech či obchodních soudech.

2. Ve druhém kroku pak zpracovatel může všechny konzultované subjekty rozdělit do několika skupin např́iklad s ohledem na to, jak moc se jich připravovaný [projekt či] dokument může dotknout. $V$ průběhu konzultačního procesu se pak může zpracovatel podle svého uvážení přednostně zaměřit na ty aktéry, kteř́ budou daným rozhodnutím ovlivněni nejvíce (přitom ale nesmí opomíjet i ostatní konzultované subjekty)." (MV ČR, 2010)

Při zpřesňování seznamu aktérů může být dle Enserinka (2010) ku pomoci několik pravidel; je totiž třeba:

a) dbát na podobu mezi rozsahem řešeného problému a množstvím analyzovaných aktérů. Pracujeme-li s místním problémem, mohou hrát aktéři na národní úrovni (vláda, ministerstvo, grantové agentury) významnou roli při nastavování pravidel či poskytování zdrojů, do konkrétního rozhodovacího procesu se však aktivně nezapojují.

b) usilovat o to, aby seznam aktérů vyváženě reprezentoval různé zájmy a názory. Pokud je to možné, každou skupinu s podobnými zájmy by měli zastupovat 2 až 3 aktéři mající různé role.

c) respektovat jednoduché pravidlo o ideálním počtu aktérů, což je přibližně 10 až 20 subjektů; více aktérů indikuje příliš nepřesně vymezené hranice problému - to s sebou nese riziko nedostatečně zacílené a pro praxi využitelné analýzy (Enserink et al, 2010).

\section{Charakteristika aktérů}

Kvalitní popis jednotlivých aktérů je považován za nejdůležitější část analýzy. $V$ této fázi jsou využity výsledky empirického výzkumu (rozhovory s klíčovými aktéry a experty, studia dokumentů a dalších zdrojů informací). Důležitým principem je kombinování různých zdrojů informací a jejich ověřování tak, aby nedocházelo k záměrnému nebo neúmysInému zkreslování závěrů. Zvláště v situaci, kdy se střetávají vyhraněné postoje vůči možným alternativám řešení problému, je pravděpodobnost snahy některých aktérů manipulovat s informacemi ve vlastní prospěch zvýšená. Záleží pak na realizátorovi analýzy, aby informace, které o případu shromažd'uje, odpovídaly cíli a kladeným otázkám a aby byly platné a díky tomu, že je Ize ověřit, také spolehlivé (validní a reliabilní). Zde se může uplatnit postup zmíněný již při identifikaci aktérů: zapojení skupiny místních, vyváženě vybraných zástupců různých názorových a zájmových proudů, kteři si navzájem zabraňují v manipulaci s výsledky.

\footnotetext{
${ }^{2}$ Zde je citován materiál Ministerstva vnitra ČR (MV ČR, 2010), který v sekci „KOHO chceme do př́pravy materiálu zapojit“ hovoří o tom, jak vytipovat široký soubor konzultovaných subjektů. Dle tohoto materiálu je DatakO „název pro databázi nevládních organizací. $\vee$ této databázi jsou veřejně přístupné organizace, které vyjádřily ochotu spolupracovat s orgány státní správy, na prípravě materiálů legislativní i nelegislativní povahy. Úřady mají možnost vybrat si při prípravě materiálů $v$ databázi nevládní organizace a projednat s nimi připravované materiály".
} 
Nevyvážený výběr aktérů s sebou nese obdobné riziko, jako kdybychom v participativním rozhodování soustředili veškeré zapojení veřejnosti do jednoho veřejného projednání. Snadno se pak může stát, že jedna dobře připravená skupina ovládne toto projednávání, aniž by se přitom jednalo o skutečný (reprezentativní) obraz rozložení názorů mezi zúčastněnými aktéry. Podobně jako je vhodné při participaci kombinovat více technik (anketa, kulaté stoly, veřejné projednání, apod.), je při analýze aktérů zapotřebí kombinovat různé zdroje informací, abychom se vyhnuli zkresleným závěrům. Při určení aktérů a vytipování těch důležitých (jejich prioritizaci) je možné využít škálu postupů, které vycházejíz cílů analýzy (důraz na aktéry s větším vlivem na výsledek projektu či jiné intervence) a/nebo jsou založeny na zjištování názorů zúčastněných stran (např. rozdělování fiktivních hlasů).

Metodika PAKT (2015b: 34) uvádí př́iklad dvou skupinových technik pro mapování aktérů: rychlý, v podobě vytvoření širšího seznamu aktérů, ze kterého tým vybírá klíčové hráče hlasováním o jejich významnosti posouváním lístečků se jmény na soustředných kružnicích a podrobnější, obdobný např. hodnocení více kritérií (viz tabulka 1) nebo níže uvedenému hodnocení profilu aktérů (tabulka 2), kdy se tým hodnotitelů zabývá dvěma základními kritérii: vliv aktéra, jeho moc, schopnost ovlivnit výsledek (malý/velký) a zájem vstoupit do rozhodovacího procesu (velký/malý), podle Veselý a Nekola (2007).

Na základě ověřených informací je pak možno zhodnotit charakteristiky jednotlivých aktérů. Cílem je strukturovat seznam aktérů vzhledem $\mathrm{k}$ danému problému a vzájemným vztahům. Opět je možné postupovat s různou mírou formality; mapování aktérů je např́klad možno provést formou kolektivního hodnocení v expertní skupině, jak o ní hovoří např. metodika PAKT (2015b: 35). Oporu pro zvolený postup Ize také hledat $v$ některých teoriích z oblasti politických a sociálních věd, které slouží k popisu pozic a rolí aktérů a jejich silných stránek a vlivu (Burandt et al, 2015). K vytvoření profilů jednotlivých aktérů se pak využívají podrobnější proměnné (indikátory), které se hodnotí na ordinální škále ${ }^{3}$, jak vidíme v Tabulce 2. Takové hodnocení charakteristik jednotlivých aktérů by mělo být provedeno nezávisle minimálně třemi hodnotiteli, aby se zvýšila spolehlivost výstupů (princip triangulace).

Pokud se například rozhodneme porovnávat více případů rozhodování v otázkách regionálního udržitelného rozvoje a naším cílem je nalézt podporu nebo korekci pro teoretické předpoklady o participativním rozhodování (viz kapitola Definice problému), pak pro popis aktérů můžeme zvolit proměnné (indikátory) obdobné těm, které $v$ rámci porovnání českých př́padů sledovali autoři této metodiky:

aktéři a jejich role ve vztahu k udržitelnému rozvoji (iniciátor, aktivní v realizaci/proti realizaci; spravuje finance); komunikace forma (tváří v tvář/zprostředkovaná) a charakter (konstruktivní /smíšená/ konfliktní); proces (top-dwn/smíšený/bottom-up; uzavřený/ ne zcela otevřený/ otevřený); výsledek (vůbec nenaplněn, částečně splněn, splněn, př́ínos navíc); rozsah případu a typ vize/projektu (konkrétní problém, krátkodobý/ komplexní, střednědobý/ koncepční/dlouhodobý); dopad na sociální kapitál (vztahy mezi aktéry); výskyt sociálního učení (kdy se aktéři vzájemně obohacují a díky spolupráci vzniká řešení, které by jinak nebylo možné); role vědců (bez vlivu na rozhodování až po angažovaného vědce); střet zájmů (ano/ potenciální/ ne), nebo lze využít některé z mnoha proměnných, které využívá tým německých kolegů (Newig et al, 2013).

\footnotetext{
${ }^{3}$ Jedná se o škálu, která udává jasné pořadí jednotlivých hodnot, nemůže však měřit velikost rozdílu mezi nimi: např. 1 = slabý, 2 = střední, 3 = silný. Na rozdíl od tzv. kardinální škály, kdy kromě pořadí můžeme přesně určit i rozdíl mezi jednotlivými hodnotami (např. věk nebo výška).
} 
Tabulka 2. Hodnocení profilu jednotlivých aktérů na škále vyjadřující míru souhlasu hodnotitele s uvedeným tvrzením o konkrétním aktérovi: -- = zcela nesouhlasím, - = spíše nesouhlasím, + = spíše souhlasím, ++ = zcela souhlasím; nebo (cf. Burandt, 2015, Zimmerman, Maennling, 2007)

\begin{tabular}{|c|c|c|c|c|c|}
\hline \multirow[t]{2}{*}{ Indikátor / Kategorie } & \multicolumn{4}{|c|}{$\begin{array}{l}\text { Zhodnocení na } \\
\text { vybrané ordi- } \\
\text { nální škále }\end{array}$} & \multirow[t]{2}{*}{ Popis } \\
\hline & -- & - & + & ++ & \\
\hline \multicolumn{6}{|l|}{$\begin{array}{l}\text { \# } 1 \text { Tvorba vize: Zhodnocení postupu vytváření vize udržitelného rozvoje. } \\
\text { Kritéria zahrnují: respektování demokratických principů, vyvážení zájmů, } \\
\text { transformativní akce a postoje, zájem na dlouhodobém řešení, použití re- } \\
\text { levantních informací. }\end{array}$} \\
\hline \multicolumn{6}{|l|}{$\begin{array}{l}\text { \# } 2 \text { Flexibilita a inovace: Otevřenost novým myšlenkám a schopnost } \\
\text { adaptovat aktivity. } \\
\text { Kritéria zahrnují: toleranci, kritické postoje, empatii, ochotu učit se a mě- } \\
\text { nit (se) }\end{array}$} \\
\hline \multicolumn{6}{|l|}{$\begin{array}{l}\text { \# } 3 \text { Vztahy: Zapojení do sítí, získávání kontaktů, vytváření prostoru pro } \\
\text { komunikaci, respekt k odlišným názorům }\end{array}$} \\
\hline \multicolumn{6}{|l|}{$\begin{array}{l}\text { \# } 4 \text { Komunikace: Konzistentní postoje a schopnost komunikovat s ostat- } \\
\text { ními aktéry, ochota informovat ostatní, otevřená a participativní výměna } \\
\text { informací, rychlé reakce }\end{array}$} \\
\hline \multicolumn{6}{|l|}{$\begin{array}{l}\text { \# } 5 \text { Transparentnost: Vlastnictví transparentních pokynů a strategií, jasné } \\
\text { role a zodpovědnosti }\end{array}$} \\
\hline \multicolumn{6}{|l|}{$\begin{array}{l}\text { \# } 6 \text { Důvěra: Proaktivní a transparentní tok informací, sdílení plánů a stra- } \\
\text { tegií, porozumění pro zájmy ostatních, spolehlivost a schopnost dodržo- } \\
\text { vat časové plány }\end{array}$} \\
\hline \multicolumn{6}{|l|}{$\begin{array}{l}\text { \# } 7 \text { Efektivnost: Aktivity orientované na cíle a výsledky, reflexe procesů a } \\
\text { výsledků }\end{array}$} \\
\hline \multicolumn{6}{|l|}{$\begin{array}{l}\text { \# } 8 \text { Konflikty: Schopnost upozornit na napětí a konflikty, jejich konstruk- } \\
\text { tivní řešení, které je provedeno rychle a otevřeně }\end{array}$} \\
\hline \multicolumn{6}{|l|}{$\begin{array}{l}\text { \# } 9 \text { Zdroje: Finanční nezávislost a vztahy s ostatními aktéry vzhledem ke } \\
\text { zdrojům }\end{array}$} \\
\hline $\begin{array}{l}\text { Vysvětlivky: } \\
\begin{array}{l}\text { - Indikátory jsou založeny na kvalitativním zhodnocení } \\
\text { - Míra souhlasu s tvrzením je definovaná na vybrané škále, např. --/++ } \\
\text { - Popis - poznámky, které mohou pomoci v dalších fázích procesu }\end{array}\end{array}$ & & & & & \\
\hline
\end{tabular}




\section{Charakteristika sítě aktérů}

Po identifikaci aktérů a jejich charakterizaci je vhodné dále analyzovat a graficky znázornit vztahy v celé jejich síti. $V$ této fázi je středem zájmu především celkové uspořádání sítě aktérů a jejich vzájemná komunikace.

Nejjednodušším přístupem je analýza propojení jednotlivých aktérů, tj. vyznačení, kdo s kým komunikuje (formou „ano/ne“ a prípadně zhodnocením kvality komunikace na zvolené škále). Toto hodnocení může být provedeno využitím sociometrické metody, kdy jsou vztahy zaznamenané do tabulky (sociomatrix), která může být dále graficky zobrazena ve formě sociogramu (viz. Obr. 4). Tímto přístupem je možné získat rychlý přehled o „propojených“ a „nepropojených“ sítích (v propojených sítích jsou všichni aktéŕi propojeni alespoň s jedním jiným aktérem, Obr. 4)

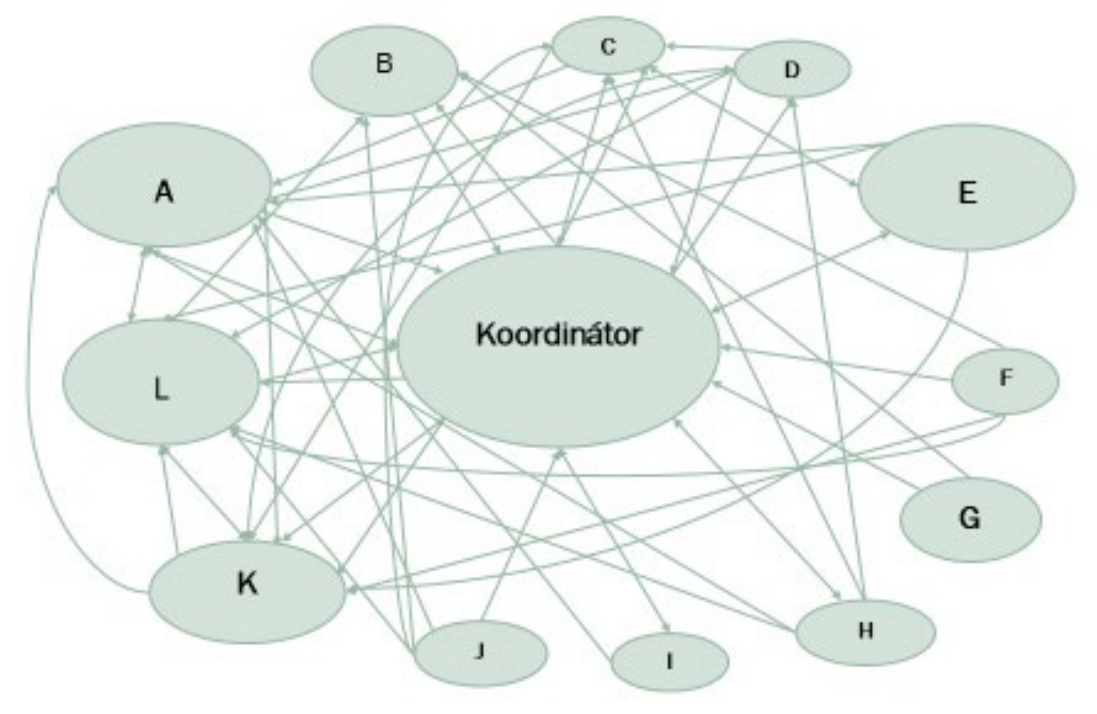

\section{Obrázek 4: Př́klad sociogramu vytvořeného v rámci evaluace spolupráce mezi aktéry projektu za- měřeného na vytváření politik pro udržitelný rozvoj}

Sociogram ukazuje všechny vazby, které byly analýzou zachyceny, naznačuje jejich směr (např. všechny šipky směřující od aktéra F k ostatním organizacím znamenají, že se tento partner zapojoval do aktivit ostatních, ale nikdo z ostatních se neúčastnil těch jeho). Dále můžeme pomocí tohoto postupu zjistit hustotu sítě, tedy kolik ze všech možných vztahů mezi aktéry je skutečně navázáno (v tomto konkrétním případě dosahuje pouze $30 \%$, ovšem po odečtení nereálných vztahů, tedy takových, které z nějakého důvodu nemohou existovat, vykazuje graf solidní hodnotu 56\%).

Hustota vztahů mezi konkrétními partnery naznačuje, kde hledat nejaktivnější „týmové hráče“ (zcela zřejmá je na obr. 4 ústřední role koordinátora). Popis jednotlivých propojení lze dále kombinovat s vyjádřením kvality vztahů, kdy např. aktér $B$ patř́ k průměrným, co se týče četnosti jeho vztahů s ostatními, ovšem žádný z jím navázaných vztahů nebyl hodnocen jako „silný“ (obr. 5) 


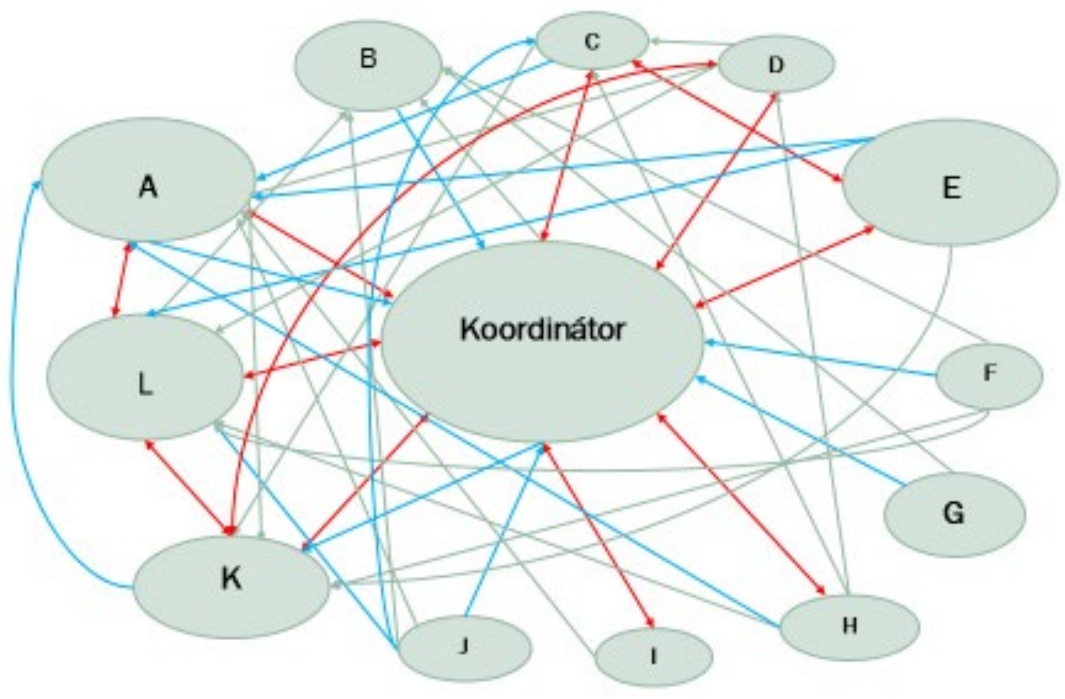

Obrázek 5. Příklad téhož sociogramu se zahrnutím kritéria kvality vztahů (červeně „silné“ vazby skutečné kooperace, modře „aktivní vztahy“ a zeleně „existující vztahy“ bez aktivní spolupráce).

Lze také hodnotit celkové uspořádání sítě, např. její centrálnost nebo segmentaci (zda existuje jeden či více ústředních aktérů), strukturní mezery a mosty (aktéry, kteří propojují oddělené skupiny). Z obr. 5 je např́klad patrná skupina úzce kooperujících aktérů (koordinátor, $A, L, K$ ), kteří tento fakt potvrdili i v dotazníku doplňujícím údaje zjištěné z projektových dokumentů a pozorování.

\section{Interpretace výsledků}

Důležitým krokem v této fázi analýzy je srovnání výsledků - odpovědí na otázky položené při vymezení problému či zadání $A A$ - s počátečním očekáváním a předpoklady. Je nutné věnovat pozornost interpretaci toho, co se nově zjistilo, a to vzhledem $\mathrm{k}$ místním podmínkám a celkové povaze zkoumaného případu: především jeho cílům a změně, kterou přináší či sleduje (např. přijetí strategie nebo realizace projektu). Výstupem tak může být např. návrh dalšího postupu v daném př́ípadě, a to s ohledem na otázky místního udržitelného rozvoje.

V tomto kroku se ukazuje, kteří aktéři změnu podporují, jsou vưči ní lhostejní nebo jí aktivně brání; na to pak Ize navázat praktické kroky a opatření při zapojování aktérů do procesu změny, zlepšování vztahů atd. Při tomto postupu vznikají další otázky, a/nebo mohou být uplatněny nové analytické nástroje, viz níže. Celkově tato fáze směřuje například k návrhu dalšího postupu vzhledem k regionálním aspektům udržitelného rozvoje.

Pro analýzu aktérů bude důležité při interpretaci zjištění zhodnotit též kvalitu sítě aktérů: zda jsou aktéři dostatečně propojeni, zda existuji vztahy umožňující spolupráci v rámci participace, dále pak určit chybějící spojení a za účelem praktického řešení dohledat skupiny se silným zapojením v kvalitních vztazích spolupráce, a hlavně aktéry schopné propojovat ostatní. 
Příkladem interpretace zjištění může být i výstup z porovnání př́ípadových studií z českého prostředí, kdy se ukázalo, že mezi důležitými aktéry se pravidelně objevují místní obyvatelé, jejich role je však v různých kauzách odlišná. Někdy stojí na straně prosazování vize udržitelného rozvoje, jindy jsou naopak v opozici - to se týká zvláště otázek ochrany přírody a krajiny. Při bližším zkoumání tohoto závěru se, v souladu se zahraničními zkušenostmi, objevují dva základní scénáře vztahu místních obyvatel k životnímu prostředí. Bud' vnímají zpřísnění pravidel ochrany přírody (např. v souvislosti se záměrem vyhlásit novou CHKO) jako ohrožení vlastních životních př́ležitostí a staví se (obvykle podporováni nějakým silným ekonomickým hráčem, který vnímá přírodu především jako tradiční ekonomický zdroj) do opozice vůči vizi ochrany prírody. Nebo nastává opačná situace, kdy místní obyvatelé vnímají negativní dopady, které by na jejich kvalitu života mělo zhoršení stavu životního prostředí díky např. novému developerskému projektu, či existenci výroby znečištujujíi své okolí. $V$ tomto scénáři se staví po bok ekologických nevládních neziskových organizací a např. angažovaných vědeckých pracovníků a společně prosazují zachování a ochranu kvalitního životního prostředí. Důležitý pro interpretaci proměnlivé role místních obyvatel je fakt, že klíčem k jejímu rozpoznání není převažující zájem o životní prostředí jako takové, ale vnímaný dopad projektu na jejich kvalitu života.

Jiný příklad interpretace lze převzít ze zkoumání sady celkem 45 př́padů z databáze Národní sítě zdravých měst ČR, které se týkají zapojování veřejnosti do rozhodovacích procesů. I když se jedná o databázi příkladů dobré praxe implementace Místní agendy 21, u které je předem zřejmé, že bude obsahovat pouze úspěšné prípady, je možné vyzdvihnout zjištění, že ačkoliv v téměř polovině př́padů existoval potenciál střetu zájmů (47\%), pouze $v$ jednom prípadě $k$ němu skutečně došlo. Vysvětlením je kvalitně připravený proces komunikace $s$ veřejností, který je $v$ rámci NSZM předáván jako ustálený formát veřejných projednání, obvykle v kombinaci s dalšími technikami (jako např. anketou Desatero problémů města), a tento ověřený přístup je při řešení otázek místního rozvoje používán od samého začátku řešení problému.

Vzhledem k převažujícím kvalitativním postupům v rámci analýzy aktérů je vhodné výsledky a jejich interpretaci konzultovat $s$ jednotlivými aktéry a dalšími nezávislými odborníky. $V$ tomto kroku je také důležité zdůraznit omezení použitých metod. Následně je možné také navrhnout praktická řešení a opatření.

\section{Návrh praktických řešení}

$\checkmark$ tomto kroku je možné na základě předešlých poznatků vypracovat finální grafickou reprezentaci výsledků, dokument s návrhem dalšího strategického postupu, či předložit jiné praktické řešení/opatření.

Př́klad praktických doporučení:

V př́padě prípravy podkladů pro strategický plán rozvoje obce se ukázalo, že obdobně jako v případě názorů na fungování Národního parku, na jehož území se obec nachází, se veřejnost dělí odlišných názorových skupin, které ve vztahu k rozvoji obce zaujímají vlastní pohled na využití potenciálu okolní př́rody. Část místních obyvatel má zájem využít umístění obce pro posilování turistického ruchu např. výstavbou lyžařského vleku, budování ubytovacích kapacit, sportovišt́ a turistických atrakcí jako lanový park, apod. Jiná část místních občanů se kloní ke konzervativnějšímu přístupu k turistickému ruchu a hledání alternativ pro obvyklý typ horské rekreace (zemědělství, malovýroba i ubytování a 
workshopy). Snaží se klást důraz na jedinečnost místa a posilovat místní identitu projekty na obnovu hřbitova nebo rekonstrukci kostela se snahou uchovat nedotčenou okolní prrírodu i původní ráz místa.

Občany obce přitom ale spojuje řada společných zájmů, výchozím bodem pro spolupráci může být fakt, že všichni současnou dlouhodobě konfliktní situaci vnímají jako problematickou a negativní. Všichni si také shodně uvědomují vzácnou kvalitu životního prostředí v obci a jejím okolí a nestaví se odmítavě k možnosti veřejného projednání priorit rozvoje obce. V dotazníkovém šetření a rozhovorech s místními aktéry se ukazuje řada názorových překryvů: jak zájem na zlepšení mezilidských vtahů, tak potřeba obživy pro místní obyvatele, zlepšování služeb a zázemí pro návštěvníky i obyvatele obce, včetně veřejných prostorů a sportovišt'. Tyto společné zájmy mohou sloužit jako prostor pro řadu budoucích aktivit a projektů. Zároveň, ačkoliv mají na způsob hospodaření Národního parku obyvatelé obce odlišné názory, se shodně vyjadřují pro existenci jasných závazných pravidel, která se nebudou měnit podle aktuální politické situace (únava konfliktem). Shodně také kritizují způsob zadávání těžebních prací v lesích Národního parku velkým firmám mimo region, kdy o možnost obživy přicházejí místní obyvatelé.

\section{Doporučení pro další postup}

Při prípravě strategického plánu rozvoje obce je třeba brát do úvahy kromě záležitostí vnitřních, které mohou přímo ovlivňovat obyvatelé obce, také vnější faktory. Tyto vnější faktory jsou sice mimo kompetenci zastupitelstva, ale zároveň významně ovlivňují a i v budoucnu budou ovlivňovat život místních obyvatel. V rámci rozhovorů s aktéry se opakovaně objevuje zejména význam Národního parku.

Externí faktory nad rámec působnosti obce:

- potřeba konzistentního a transparentního jednání a stanovení pravidel ze strany Národního parku

- podpora zaměstnanosti místních obyvatel při zakázkách těžby v Národním parku

- umožnění částečného hospodaření obce (obecní les jako zdroj palivového dřiví pro místní obyvatele a stavebního materiálu pro potřeby obecních staveb)

- spolupráce Národního parku při celkovém směřování rozvoje obce (shoda nad záměry rozvoje, nové myšlenky a impulzy, např. alternativní pracovní uplatnění, partnerské projekty NP a obce)

V rámci obce:

je možné uvažovat např. o třech základních, vzájemně se prolínajících, oblastech rozvoje, které je zapotřebí vnímat v dlouhodobé perspektivě: ekonomická (potřeba zajištění obživy), sociální (potřeba zlepšit mezilidské vztahy) a životní prostředí (potřeba uchovat vzácnou okolní prírodu jako dlouhodobou devizu života v obci). Priority rozvoje je možné hledat ve východiscích, která jsou společná pro všechny:

- potvrzení jasných pravidel rozvoje obce (územní plán zachován) bez rizik neočekávaných změn (obdobně jako u NP)

- únava konfliktem,

- vzácné životní prostředí,

- potřeba obživy pro místní obyvatele

- konkrétní kroky a doporučení:

- vybudovat obecní prostor pro setkávání občanů

- podporovat myšlenku na vytvoření místních spolků, aktivně otevírat nová témata a možnosti 
- otevřeně informovat o př́pravě strategického plánu rozvoje obce, zabývat se potenciálně konfliktními prvky a otevřeně je diskutovat

- formulovat návrh základních priorit rozvoje obce (na základě názorů obyvatel vyjádřených v dotazníkovém šetření: životní prostředí, veřejné prostory, ekonomické př́ležitosti a služby, mezilidské vztahy)

- vytvořit pracovní skupinu pro př́pravu strategického plánu rozvoje obce (se zástupci všech názorových stran)

- a uspořádat veřejné projednání k navrženým prioritám za účasti zástupců všech názorových stran, ideálně pod vedením nezaujatého facilitátora

- stavět základy spolupráce na tradicích, které nejsou vnímány jako projekt jedné nebo druhé strany (např. pout', zpívání u vánočního stromečku, stavění májky, apod.)

- a hledat nová témata spolupráce, která by nemusela být vnímána kontroverzně (např. sportoviště, obecní prostor pro setkávání).

\section{Další nástroje pro charakteristiku vztahů mezi aktéry}

Existuje škála nástrojů pro jemnější rozlišení povahy aktérů či jejich vztahů - Ize je najít v existující literatuře. Následující př́íklady jsou vybrány z (Zimmermann, Maennling, 2007).

\section{Analýza moci a mocenských vztahů:}

„Moc" je součást všech sociálních vazeb; v kontextu rozhodovacích procesů je třeba ji považovat za prostředek dosažení cílů. Může nabývat jak kladného tak i záporného významu vzhledem $\mathrm{k}$ diskutovaným strategiím nebo prosazovaným záměrům. Velmi často je zapotřebí znát mocenské rozložení sil, mj. proto, že zneužití moci má za následek určitou formu násilí. Struktury moci jsou nedílně propojeny s celou sociální strukturou a vztahy mezi aktéry; v procesech změn se mění i toto silové pole. To ovšem vyvolává napětí, které může ústit do konfliktů.

Analýza mocenských vztahů vychází z hodnocení dvou aspektů moci: legitimity a zdrojů moci.

- Legitimita moci se dále dělí na několik typů, které souvisejí s pravomocí:

- $\mathbf{N P}=$ stanovit normy a pravidla

○ $\quad \mathbf{Z}=$ alokovat nebo neposkytnout zdroje

○ $\quad \mathbf{R O}=$ definovat role a odpovědnost

- $\quad \mathbf{P R}=$ vytvářet struktury pro participaci v rozhodování

- $\quad \mathbf{I Z}$ = kontrolovat prístup $\mathrm{k}$ informacím a znalostem

- $\quad \mathbf{O S}=$ udílet ocenění nebo sankce

- $\quad \mathbf{P Z}$ = předávat zprávy externím hráčům nebo institucím

Výsledkem v tomto případě je souhrnné hodnocení, tedy zjištění „celkové“ moci daného aktéra (viz tabulka 3). Jednotlivým typům legitimity Ize přitom přidělit různou váhu: některé typy považujeme za důležitější než jiné, a proto jejich hodnotu zvýrazníme. Např. vynásobením koeficientem vycházejícím z žebříčku typů legitimity, který jsme ve vztahu k řešenému problému sestavili ve spolupráci s dalšími hodnotiteli (či se skupinou místních expertů). Nemusí se přitom jednat o úplný žebřriček, ale například o zdůraznění práva alokovat zdroje, stanovit normy a definovat role vynásobením koeficientem 1,5 (přiklad z tabulky 3 by pak přinesl u aktéra 1 hodnoty NP=4,5, Z=1,5 a RO=3 a celková hodnota by činila 16). 
Tabulka 3. Hodnocení mocenských vztahů pro jednotlivé typy legitimity na škále 1-3. Zdroj: (Zimmerman, Maennling, 2007)

\begin{tabular}{|l|l|l|l|l|l|l|l|l|}
\hline $\begin{array}{l}\text { Typy le- } \\
\text { gitimity }\end{array}$ & NP & Z & RO & PR & IZ & OS & PZ & Celkem \\
\hline Aktér 1 & 3 & 1 & 2 & 1 & 2 & 1 & 3 & $\mathbf{1 3}$ \\
\hline Aktér 2 & 2 & 3 & 1 & 1 & 1 & 1 & 3 & $\mathbf{1 2}$ \\
\hline Aktér 3 & & & & & & & & \\
\hline
\end{tabular}

- Zdroje moci, ke kterým mají aktéři prístup:
o informace
- komunikace a schopnost vyjednávání
o odborné znalosti a expertiza
- relevance pro praxi
○ kreativita
○ sociální vztahy

Zdroje moci lze vyhodnotit pomocí hexagramů (obr. 6), nicméně takové hodnocení je poměrně subjektivní. Z hexagramů Ize např́klad vyvozovat potenciální nebo reálné vztahy mezi aktéry, rozdíly mezi nimi, oblasti, kde si konkurují o zdroje nebo se vzájemně doplňují atd.

Obrázek 6. Hexagram ukazující rozložení zdrojů moci jednotlivých aktérů: $v$ tomto prípadě jsou označeni plnou a přerušovanou čarou (zde jde dva aktéry). Zdroj: (Zimmerman, Maennling, 2007)

IN - Informace (Information): kontrola informačních toků a obsahů

CN - Komunikace a schopnost vyjednávání (Communication \& Negotiating): schopnost formulovat problém a efektivně jej sdělit, takže ostatní jsou přesvědčeni o jeho správnosti

KE - Odborné znalosti a expertiza (Knowledge \& Expertise): znalosti, jimiž ostatní nedisponují, ale jež jsou nutné k dosažení cíle

PR - Relevance pro praxi (Practical Relevance): doved-

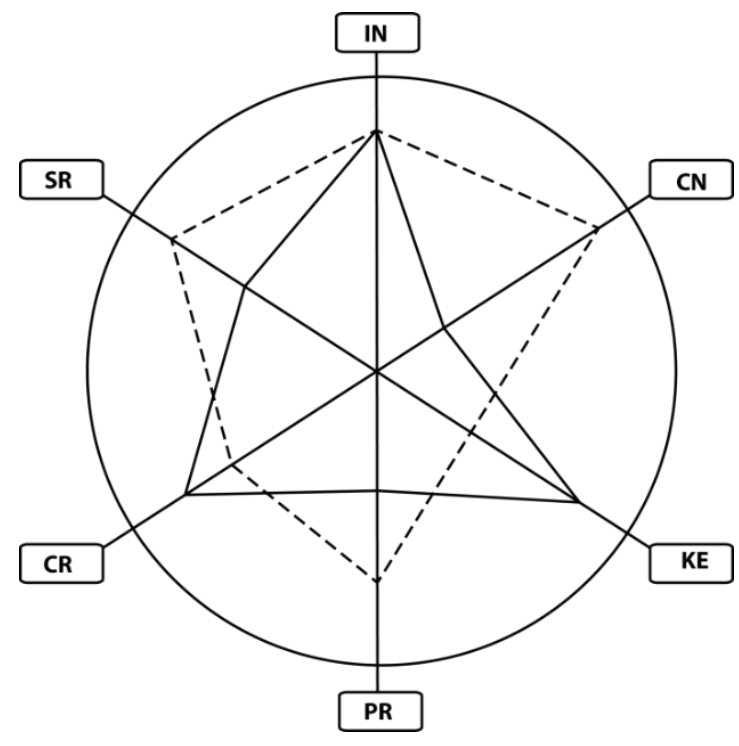
nosti a zkušenost v nakládání se znalostmi, které vedou k řešení problémů a prosazení změn CR - Kreativita (Creativity): schopnost využívat znalosti a zkušenost takovým způsobem, že vznikají nové myšlenky, koncepty a řešení, a/nebo se na problémy nahliží inovativním způsobem SR - Sociální vztahy (Social Relations): moc odvozená z členství ve společenských skupinách, třídách nebo organizacích a zajištovaná vztahy s dalšími aktéry. 


\section{Analýza angažovanosti a vlivu}

Tato analýza umožňuje vytvářet strategie pro zapojení aktérů. K tomu slouží dvě otázky: Jaký je vztah aktéra k plánované změně nebo intervenci? (v rozpětí mezi odmítnutím - príjetím), a Jaký je jeho vliv na dosažení této změny? (v rozpětí mezi malým vlivem - významným vlivem). Otázky lze zodpovědět na škále -2 až +2 a vyhodnotit na základě tabulky podobně jako při hodnocení mocenských vztahů. Výsledkem je v tomto případě umístění aktérů v grafu mezi př́slušnými souřadnicemi - viz obr. 7. Podle tohoto grafického znázornění pak Ize plánovat, jak jednotlivé aktéry participativně zapojit do procesu změny.

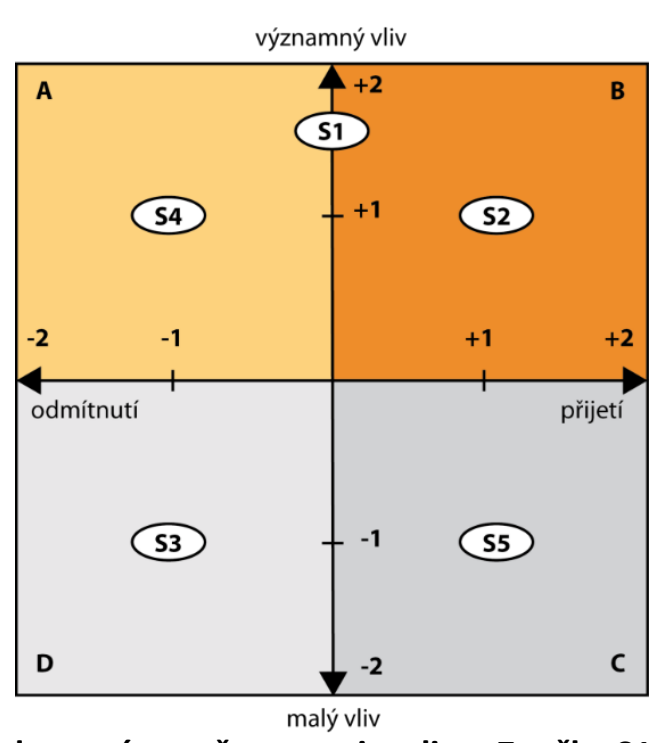

Obrázek 7. Vizualizace hodnocení angažovanosti a vlivu. Značky S1 S5 označují postavení jednotlivých aktérů v souvislostech procesu změny. Zdroj: (Zimmerman, Maennling, 2007)

\section{Budování dưvěry}

Často je potřeba vědět, zda existuje základ pro vzájemnou důvěru, anebo panuje zásadní nedůvěra mezi aktéry. Tím se vyjasní možnosti vytváření různých aliancí, koalic a sítí spolupráce. Protože (ne)důvěra je implicitní součástí vztahů, není možné klást tuto otázku explicitně a je třeba formulovat pracovní hypotézy a ty pak testovat v praxi. Přibližně je možno hodnotit vztahy (ne)důvěry v matici aktérů napríklad takto:

Tabulka 4. Hodnocení (ne)důvěry mezi aktéry na škále 1 (zjevná nedůvěra), 3 (malá důvěra) až 5 (důvěra). Zdroj: (Zimmerman, Maennling, 2007)

\begin{tabular}{|l|l|l|l|l|l|l|}
\hline $\begin{array}{l}\text { Typy auto- } \\
\text { rity }\end{array}$ & Aktér 1 & Aktér 2 & Aktér 3 & Aktér 4 & Aktér 5 & $\begin{array}{l}\text { střední hod- } \\
\text { nota „důvě- } \\
\text { řuje jiným“ }\end{array}$ \\
\hline Aktér 1 & & 4 & 5 & 4 & 3 & 4 \\
\hline Aktér 2 & 4 & & 4 & 2 & 1 & 3 \\
\hline Aktér 3 & 3 & 5 & & 2 & 1 & 2,5 \\
\hline Aktér 4 & 1 & 4 & 2 & & 3 & 2,5 \\
\hline Aktér 5 & 1 & 5 & 4 & 2 & 2 & 3 \\
\hline $\begin{array}{l}\text { střední hod- } \\
\text { nota ,je mu } \\
\text { důvěro- } \\
\text { váno“ }\end{array}$ & 2 & 4,5 & 4 & 2 & & \\
\hline
\end{tabular}


V procesech vyjednávání pak hraje roli především „investice“ aktéra do komunikace, otevřenosti a vlivu, přičemž odezva od jeho protějšku může být naopak obrana a tedy nedůvěra. Jinými slovy akce na posílení důvěry musí sledovat křehkou rovnováhu a nevychylovat ji př́liš ani jedním směrem - většinou se ustálí na nízké hladině určené kalkulací rizik při narušení vztahů důvěry (obr 8.).

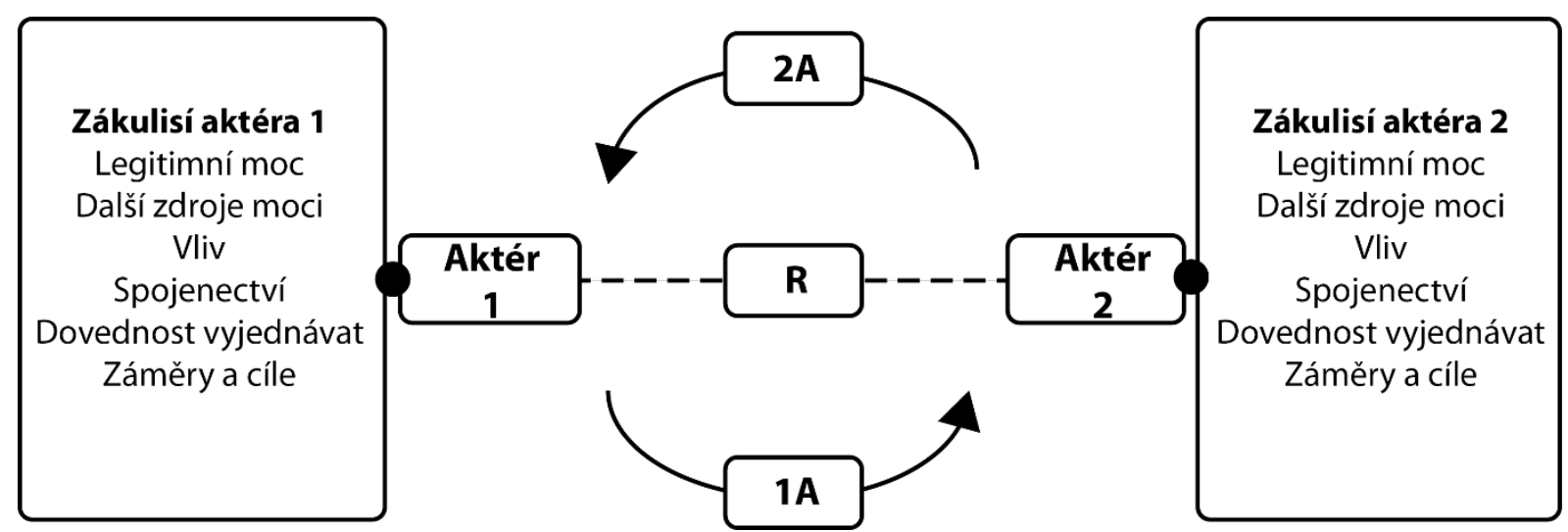

Obrázek 8. Budování vztahů důvěry mezi dvěma aktéry. 1A a $2 A$ značí investice do těchto vztahů; $R$ znamená reakci, tedy snahu dosáhnout rovnováhu na nejnižší možné úrovni v dlouhodobém horizontu. Zdroj: (Zimmerman, Maennling, 2007)

\section{Vyloučení versus zvýšení vlivu}

Zde se může projevit, kteří aktéři mají či mohou potencionálně dosáhnout vlivu, a kdo z nich prozatím tyto možnosti nemá - takže pak Ize hledat cesty $z$ této jejich situace vyloučení. $K$ takovému hodnocení je třeba vyhodnotit dva hlavní indikátory: prístup a kontrola nad zdroji (zdroji se myslí jak materiální zdroje, tak také možnost ovlivňovat politická rozhodnutí atd.); a dále základní dovednosti aktérů. Tyto aspekty Ize hodnotit na škále -2 až +2 , a to pomocí tabulky podobně jako ve výše uvedených prípadech. Výsledkem pak může být diagram znázorňující aktéry ve čtyřech polích, jak je patrno z obrázku 9.

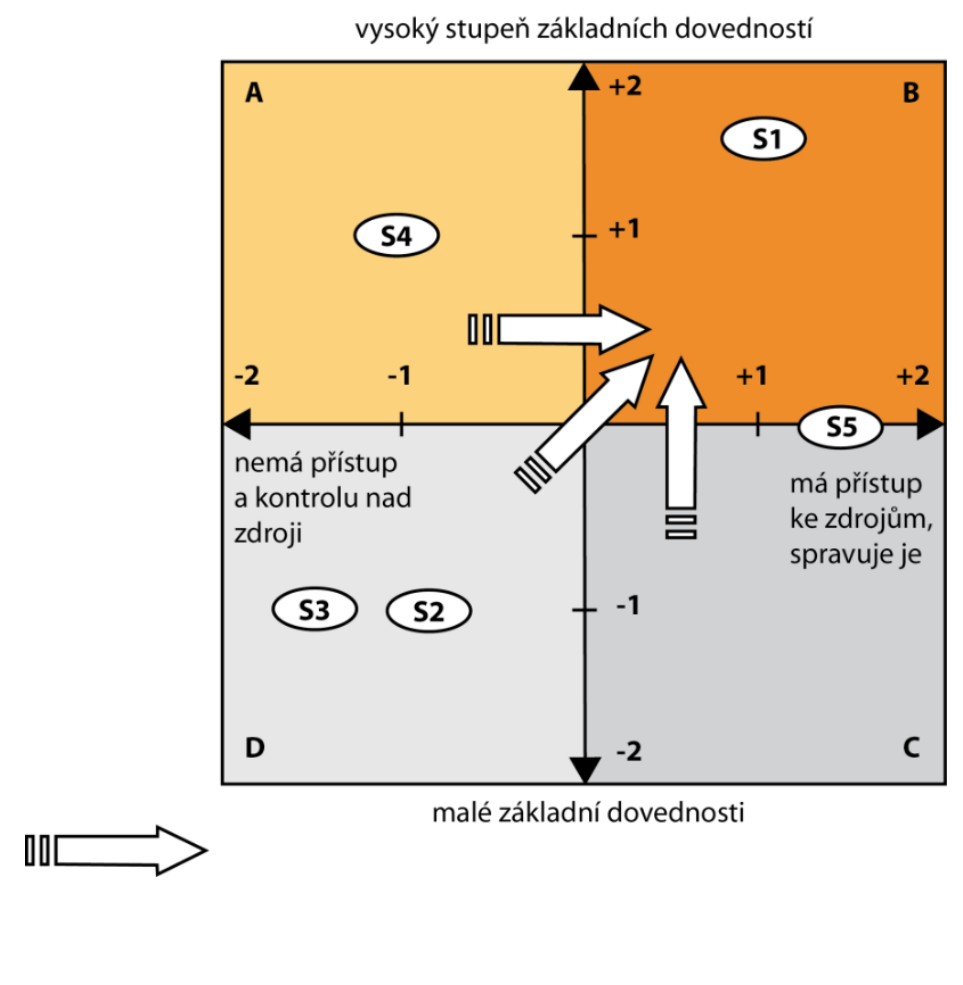

Obrázek 9. Hodnocení vyloučení versus vlivu aktérů. Šipky označují směr žádoucího posilování vlivu.

Zdroj: (Zimmerman, Maennling, 2007) 


\section{Novost metodiky}

Požadavek vyššího zapojení občanů a dalších aktérů do veřejného rozhodování je zmíněn v celé řadě mezinárodních dokumentů (OECD, Rada Evropy, EU) a stejně tak je veřejně deklarován i Vládou ČR (Metodika zapojení veřejnosti do př́pravy vládních dokumentů, Ministerstvo vnitra 2009).

Metodika se v praxi využívá tam, kde může pomoci řešit nějaký problém, př́padně ošetřit zvláštnosti různých prostředí. Ve státech, jako je např. Velká Británie, Nizozemí nebo Švédsko, je při rozhodování v různých oblastech rozvoje (včetně urbanistického, sociálních služeb, managementu životního prostředí, apod.) obvyklé využívání některé ze škály metod, které pracují s identifikací a analýzou relevantních sociálních skupin, jež mohou být řešením dotčeny, nebo které mají na řešení zájem a vliv. Analýza aktérů se zde zapojuje např. do urbanistických projektů a plánování obecně (Boelens, 2010). Jako nástroj pro tvorbu politik v souladu s principy regionálního udržitelného rozvoje byla zpracována např́klad německým Ministerstvem pro ekonomickou spolupráci a rozvoj a uplatněna např. při př́pravě programů na podporu zaměstnanosti mladých v urbánních oblastech Senegalu (Zimmermann, Maennling, 2007). V kontextu udržitelného rozvoje nachází AA uplatnění především ve studiích zabývajících se otázkami životního prostředí, jako je změna klimatu (Kivimaa et al. 2015; BACC Author Team, 2008) nebo hospodaření s vodními zdroji (Wever et al., 2015; Burandt et al. 2015).

V ČR existuje „Manuál pro zapojování veřejnosti do přípravy vládních dokumentů” z r. 2010, který navazuje na Metodiku pro zapojování veřejnosti do přípravy vládních dokumentů, kterou vláda České republiky schválila usnesením č. 1146 k Metodice pro zapojování veřejnosti do přípravy vládních dokumentů v r. 2009. Manuál má doporučující charakter (MV ČR, 2010). Přes tato opatření není systematický př́stup k zapojování sociálních aktérů do rozhodovacích procesů v ČR běžný a není např. explicitně zahrnut ani ve schválené Metodice přípravy veřejných strategií Ministerstva pro místní rozvoj ČR.

Trend participativního rozhodování se postupně začíná prosazovat do praxe rozhodování na místní úrovni i v ČR. Viz př́klad implementace Místní agendy 21, která je v systému indikátorů koordinována ve spolupráci Ministerstva životního prostředí ČR a Národní sítě zdravých měst ČR, nebo príklad iniciativy PAKT usilující o prosazování systémového př́stupu k participaci ve všech sférách rozhodování veřejné správy (AKT, 2015a) a která jako jeden z důležitých kroků ve své metodice (PAKT, 2015b) uvádí právě analýzu aktérů. 


\section{Popis uplatnění metodiky}

Metodiku AA Ize využít všude, kde je zapotřebí dosáhnout lepší komunikace a vyjednávání mezi jednotlivými aktéry - to přispívá k nelezení nových řešení na otázky v oblasti udržitelného rozvoje na regionální úrovni. Snahou je zejména dobré porozumění místních sociálních interakcí a procesů a vyřešení či předejití konfliktních situací. Metoda se tedy dá využít například v př́padech, kdy je regionální rozvojové téma předmětem veřejné participace a kdy je třeba zohlednit různé pohledy a postoje jednotlivých aktérů. Konkrétně se připravuje její začlenění do aktualizace Metodiky přípravy veřejných strategií Ministerstva pro místní rozvoj ČR (MMR, 2012).

Analýzu aktérů Ize př́mo zahrnout na místní úrovni např. do tvorby plánů udržitelné mobility, pro které aktuálně zpracovalo metodiku Centrum dopravního výzkumu (Jordová et al, 2015) nebo do participativního managementu v biosférických rezervacích, který je součástí Metodiky rozvoje dlouhodobého sociálně-ekologického monitoringu (LTSER) v biosférických rezervacích ČR (Harmáčková et al 2014). Uplatnění může postup analýzy aktérů nalézt také v rámci aktivit a projektů Národní sítě zdravých měst ČR a v neposlední řadě lze jmenovat také začlenění analýzy do zajištění participace při aktualizaci Strategického rámce udržitelného rozvoje ČR na národní úrovni.

\section{Realizovaná uplatnění}

Metodika analýzy aktérů byla v rámci projektu TAČR TD020120 uplatněna na několika úrovních:

1. při analýze konkrétního případu přípravy strategického plánu rozvoje obce Prášily

2. při srovnávací analýze případových studií z ČR (Dlouhá \& Zahradník, 2015; Zahradník et al 2014)

3. při zpětné srovnávací analýze databáze Národní sítě zdravých měst ČR a porovnání s dalšími př́pady z ČR

4. při př́pravě aktualizace Strategického rámce udržitelného rozvoje ČR pro Radu vlády pro udržitelný rozvoj.

5. v době zpracování metodiky probíhá výzkum v CHKO Jizerské hory ve spolupráci s Katedrou sociální a kulturní ekologie FHS UK v rámci diplomové práce Bc Gabriely Tišerové zabývající se analýzou střetu zájmů mezi ochranou prírody a sportovně rekreačními aktivitami (cyklistika a lyžování). 


\section{Závěr}

Analýza aktérů může být praktickým nástrojem, který poskytuje strukturovaný náhled do procesů regionálního udržitelného rozvoje, napomáhá odhalit důležité vztahy, popsat stav sociálního kapitálu na regionální úrovni a tudíž také hnací síly budoucího rozvoje. Primárně je metoda zaměřena na vytváření strategií a politik k udržitelnému rozvoji, ale je stejně tak využitelná pro výzkumné a výukové účely.

Pro hlubší pochopení předností a nedostatků metody samotné a hlavně pak povahy rozhodovacích procesů v otázkách místního a regionálního udržitelného rozvoje, byla vytvořena on-line databáze Př́pady kauz udržitelného rozvoje (Enviwiki, 2015). Cílem je shromažd'ovat informace k př́padům, ve kterých dochází ke spolupráci nebo střetu více aktérů a jejich porovnáním za využití analýzy aktérů kumulovat poznání o těchto procesech. Zároveň by měla databáze sloužit i do budoucna jako prostor pro shromažd'ování informací o prípadech s konkrétním uplatněním analýzy aktérů v rozhodovacích procesech.

Pro uživatele metodiky je proto připravena možnost bud' využít předem připravený formulář případu a zpracovat informaci pro databázi samostatně, nebo kontaktovat přímo pracovníky Centra pro otázky životního prostředí Univerzity Karlovy vPraze (jana.dlouha@czp.cuni.cz; martin.zahradnik@czp.cuni.cz) a informovat je o uplatnění analýzy aktérů, případně konzultovat její aplikaci. Dosavadní zkušenosti spolu s možnými výzkumnými otázkami jsou uvedeny např. v publikacích Dlouhá \& Zahradník, 2015; nebo Zahradník, Dlouhá, Burandt, 2014.

\section{Poděkování}

Základní myšlenka využití zahraničních zkušeností pro podporu participativních procesů v ČR vznikla ve společném programu výuky Univerzity Karlovy v Praze a Leuphana University of Lüneburg v letech 2010-2013 (projekt ISPoS - International Study Programme on Sustainability - financovaný DBU). Př́pravné fáze ke zpracování této Metodiky proběhly ve spolupráci českých vysokých škola a v souvislostech s výukou programu ISPoS vedenou v projektu MOSUR (Mezioborová sít spolupráce pro policy development v oblasti udržitelného rozvoje, 2011-2014 -ESF, MŠMT ČR). Odborné základy byly položeny a samotná Metodika analýzy aktérů byla zpracována v rámci projektu TD020120 Studium a podpora procesů participativní tvorby regionálních strategií udržitelného rozvoje území s využitím metody analýzy aktérů, podpořeného Technologickou agenturou ČR v letech 2014-2015. 


\section{Publikace předcházející metodice}

Burandt, S., Gralla, F., Beatrice, J. (2015). “Analýza aktérů v případových studiích regionálního udržitelného rozvoje". Envigogika. 10 (1). DOI: 10.14712/18023061.433

Dlouhá, J., Zahradník, M. (2015). “Potential for social learning in sustainable regional development: analysis of stakeholder interaction with a focus on the role of scientists". Envigogika. 10 (1). DOI: http://dx.doi.org/10.14712/18023061.476

Zahradník, M., Dlouhá, J., Burandt, S. (2014). "Actor analysis as a tool for exploring the decision-making processes in environmental governance". in Barton, A., Dlouhá, J. Exploring regional sustainable development issues. Using the case study approach in higher education. Grosvenor House Publishing LTD. Guildford. ISBN 978-1-78148-912-3

\section{Literatura}

BACC Author Team. (2008). "Assessment of Climate Change for the Baltic Sea Basin. Regional Climate Studies. Springer". ISBN 978-3-540-72786-6

Bernard, J. (2015). Participace v ČR v sociologickém diskursu. Konference o participaci PAKT. Senát ČR. 14. 9. 2015

Boelens, L. (2010). "Theorizing Practice and Practising Theory: Outlines for an Actor-Relational-Approach in Plannig". Planning Theory. Vol 9(1): 28-62. DOI: 10.1177/1473095209346499

Dlouhá, J., Huisingh, D., Barton, A. (2013). "Learning networks in higher education: Universities in search of making effective regional impacts". Journal of Cleaner Production. 49. DOI:

10.1016/j.jclepro.2013.01.034

Dlouhá, J. (2014). "Sustainable development case studies and their use as a teaching method in regionally focused higher education programs". in Barton, J., Dlouhá, J. (eds.). Exploring regional sustainable development issues. Using the case study approach in higher education. Grosvenor House Publishing LTD. Guildford

Enserink, B., Hermans, L. Kwakkel, J., Thissen, W., Koppenjan, J. Bots, P. (2010). Policy Analysis of Multi-Actor Systems. Boom Lemma Uitgevers, imprint of Eleven International Publishing, The Hague, 175 pp. Available from: http://tudelftcourses.multimediaservices.nl/wp-content/uploads/2013/05/Course-Book-4-Actor-Analysis.pdf

Fritsch, O., Newig, J. (2012). "Participatory Governance and Sustainability: Findings of a Meta-Analysis of Stakeholder Involvement in Environmental Decision Making". in Brousseau, E., Dedeurwaerdere, T., Siebenhüner, B. (eds.) Reflexive Governance for Global Public Goods. The MIT Press. London, UK. ISBN: 9780262301954

Harmáčková, Z., Rynda, I., Vačkář, D. (2014). Metodika rozvoje dlouhodobého sociálně-ekologického monitoringu (LTSER) v biosférických rezervacích České Republiky. Centrum výzkumu globální změny 
AV ČR, v. v. i., Fakulta humanitních studií, Univerzita Karlova v Praze. Dostupné $z$ http://www.ecosystemservices.cz/userfiles/page/252/328b01dd6feb66d13585f79fff5d021a.pdf

HarmoniCOP Team. (2005). Learning together to manage together. Improving participation in water management. Harmonising collaborative planning. University of Osnabrück, Germany. Retrieved from http://www.harmonicop.uni-osnabrueck.de/HarmoniCOPHandbook.pdf

Hermans, L. M., Thissen, W. A. H. (2009). "Actor analysis methods and their use for public policy analysts". European Journal of Operational Research, 196, pp. 808-818

Hogl, K., Kvarda, E., Nordbeck, R., Pregernig, M. (2012). Environmental Governance: The Challenge of Legitimacy and Effectiveness. Cheltenham, UK ; Northampton, MA, USA: Edward Elgar Pub

Jordová, R., Sperat, Z., Brůhová Foltýnová, H., Martinek, J. (2015). Metodika pro přípravu plánů udržitelné mobility měst České republiky, Brno, Centrum dopravního výzkumu, v. v. i.

Kastens, B., Newig, J. (2007). "The Water Framework Directive and Agricultural Nitrate Pollution: Will Great Expectations in Brussels be Dashed in Lower Saxony? ". European Environment. 17(4), 231-246. DOI: $10.1002 /$ eet.446

Layzer, J. A. (2008). Natural Experiments: Ecosystem-Based Management and the Environment, MIT Press, Cambridge, Mass.

Newig, J. (2007). "Does public participation in environmental decisions lead to improved environmental quality? Towards an analytical framework". International Journal of Sustainability Communication. 1 (1)

Newig, J., Fritsch, O. (2009). “Environmental governance: participatory, multi-level - and effective?". Environmental Policy and Governance, 19(3), 197-214.

Newig, J. (2012). “More effective natural resource management through participatory governance? Taking stock of the conceptual and empirical literature - and moving forward", in Hogl, K., Kvarda, E., Nordbeck, R., Pregernig, M. Environmental Governance: The Challenge of Legitimacy and Effectiveness. Cheltenham, UK ; Northampton, MA, USA: Edward Elgar Pub.

Newig, J., Adzersen, A., Challies, E., Fritsch, O., Jager, N. (2013). Comparative analysis of public environmental decision-making processes - a variable-based analytical scheme. Institute for Environmental and Sustainability Communication. Research Group Governance, Participation and Sustainability. Leuphana University Luneburgh, Available from http://ssrn.com/abstract=2245518

OECD (2008). OECD Environmental Outlook to 2030. Paris: OECD. Dostupné z http://www.oecdilibrary.org/docserver/download/9708011e. pdf?expires=1418991901\&id=id\&ac-

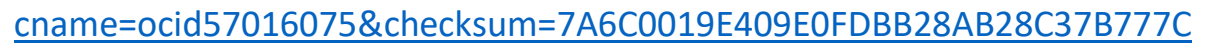

Macnaghten, P., Jacobs, M. (1997). “Public identification with sustainable development: Investigating cultural barriers to participation". Global Environmental Change. 7: 5-24. doi:10.1016/S0959-

3780(96)00023-4Ministerstvo pro místní rozvoj ČR. (2012). Metodika př́pravy veřejných strategií. Dostupné z: http://www.mmr.cz/getmedia/4ebb3cc7-6f5c-4f37-ad1f-97054a212483/metodika-pripravy-verejnych-strategii_listopad-2012.pdf 
Ministerstvo vnitra. (2009). Metodika zapojení veřejnosti do prípravy vládních dokumentů, Dostupné z: http://www.vlada.cz/assets/ppov/Irv/ria/metodiky/Metodika-pro-zapojovani-verejnosti-do-pripravy-vladnich-dokumentu.pdf

MV ČR (2010). Manuál pro zapojování veřejnosti do př́pravy vládních dokumentů Ministerstvo vnitra, odbor efektivní veřejné správy. Online dostupné na www.mvcr.cz/soubor/manual-doc.aspx

PAKT. (2015a). Analýza občanské participace v České republice. Mička, P. (ed.), Agora CE, o.p.s. Dostupné z: http://www.paktparticipace.cz/dokumenty/analyza

PAKT. (2015b). Metodika participace aneb jak spolupracovat s občany. Mička, P. (ed.) Pracovní verze doposud nepublikovaného textu dostupná z: http://www.paktparticipace.cz/dokumenty/metodikaparticipace

Pellizoni, L. (2003). "Uncertainity and Participatory Democracy”. Environmental Values. 12: 195 -224. DOI: 10.3197/096327103129341298

Pergler, P. (2015). Interní podklady pro jednání Platformy UR, COŽP UK

Enviwiki (2015). “Př́pady kauz udržitelného rozvoje”. Dostupné z: http://www.enviwiki.cz/wiki/Kategorie:P\%C5\%99\%C3\%ADpady kauz udr\%C5\%BEiteln\%C3\%A9ho rozvoje

Stachová, J., Bernard, J., Čermák, D. (2009). Sociální kapitál v České republice a v mezinárodním srovnání. Sociologické studie, 5. Sociologický ústav AV ČR, v.v.i.

Steele, J. (2001). "Participation and Deliberation in Environmental Law: Exploring a Problem-solving Approach". Oxford Journal of Legal Studies. 21(3): 415-442. doi: 10.1093/ojls/21.3.415

Strategický rámec udržitelného rozvoje ČR (2010). Usnesení vlády ČR č. 37. MŽP ČR, http://www.mzp.cz/cz/strategie udrzitelneho rozvoje

Veselý, A., Nekola, M. (2007) Analýza a tvorba veřejných politik: př́stupy, metody a praxe. Praha: Sociologické nakladatelství, 2007. ISBN 978-80-86429-75-5

Zimmermann, A., Maennling, C. (2007). Mainstreaming participation. Multi-stakeholder management: Tools for Stakeholder Analysis. Federal Ministry for Economic Cooperation and Development. Deutsche Gesellschaft fur Technische Zusammenarbeit (GTZ) GmbH, Eschborn. 30 January 2014, Dostupné z: http://www.fsnnetwork.org/sites/default/files/en-svmp-instrumente-akteuersa$\underline{\text { nalyse.pdf }}$ 